Check for updates

Cite this: Anal. Methods, 2020, 12, 1014

\title{
Industrial applications of laser-induced breakdown spectroscopy: a review
}

\author{
S. Legnaioli, ${ }^{a}$ B. Campanella, ${ }^{a}$ F. Poggialini, ${ }^{a}$ S. Pagnotta, (D) a M. A. Harith, (D) ${ }^{\text {b }}$ \\ Z. A. Abdel-Salam ${ }^{\text {b }}$ and V. Palleschi (iD *a
}

Received 21st December 2019

Accepted 3rd February 2020

In this review we present a short, although comprehensive, review on the industrial applications of laserinduced breakdown spectroscopy (LIBS). Attention has been devoted to the applications where LIBS can potentially make a difference with respect to other traditional techniques, namely steel and coal industries, and new emerging applications, where the intrinsic features of LIBS are particularly interesting, such as sorting of waste for selective recycling.

rsc.li/methods

\section{Introduction}

Laser-induced breakdown spectroscopy is an emerging analytical technique, which has attracted the attention of the spectrochemistry community due to the intrinsic simplicity of the experimental apparatus and the possibility of performing remote elemental analysis in a very short time, without the need for pre-treatment of samples. ${ }^{1}$

Many authors while describing the characteristics of LIBS start, in the introduction of their papers, with the description of the many different fields of application of laser-induced breakdown spectroscopy. Among them, a very generic term 'Industrial Applications' is always present, accompanied by a few references, often quoting the studies of the same authors or, in the best cases, some of the excellent reviews or book chapters that have been published in recent past. $^{2-5}$

A search on the Scopus ${ }^{\circledR}$ database with keywords (("LaserInduced Plasma Spectroscopy" OR "Laser-Induced Breakdown Spectroscopy") AND ("industry" OR “industrial”)) reports about 500 papers in 35 years, starting with the manuscript published by Hartford et al. ${ }^{6}$ in 1983 about possible industrial applications of the then newborn LIBS technique and ending with the 65 papers published on the same topic in 2019.

Important recent developments in LIBS analysis, related both to the improvements of the experimental setups, with the introduction of mobile double-pulse systems, ${ }^{7-9}$ for example, and to the development of efficient machine learning techniques ${ }^{\mathbf{1 0 - 1 4}}$ that allow acquisition of informative spectra and the analysis of large quantities of data in real time, have boosted the interest in out-of-the-lab applications of LIBS, among which

${ }^{a}$ Applied and Laser Spectroscopy Laboratory, Institute of Chemistry of Organometallic Compounds, Area della Ricerca del CNR, Via G. Moruzzi, 1-56124 Pisa, Italy. E-mail: vincenzo.palleschi@cnr.it

${ }^{b}$ National Institute of Laser Enhanced Science (NILES), Cairo University, Giza 12613, Egypt industrial applications appear to have benefitted from most of these technological advances.

As for the general literature in LIBS, the studies related to industrial applications have also increased exponentially in time (see Fig. 1).

However, as discussed in ref. 15, most of the results presented in the literature as industrial applications of LIBS should be considered, more realistically, as 'proofs of principle' often paid for by public research organizations and somewhat forgotten at the end of the project, after the publication of a couple of papers on the results obtained. On the other hand, it is also fair to consider that the important results obtained using LIBS in the industrial fields are probably not disclosed, for preserving the value of the research investment of the industrial partner.

Maintaining our discussion on what is available in the literature, beyond the plethora of generic references, in a few

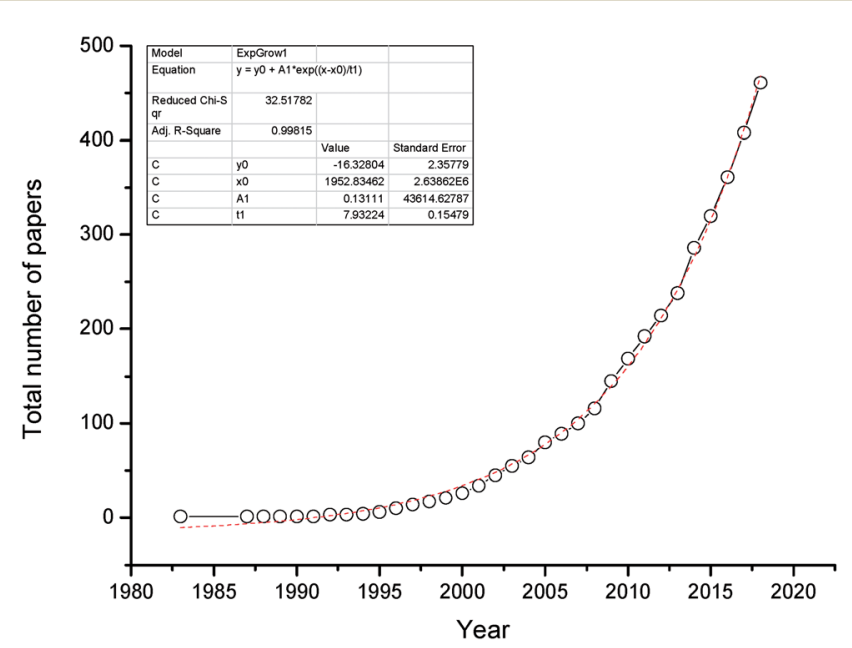

Fig. 1 Total number of papers published since 1987 referring to industrial application of LIBS. The red dashed line is the best exponential fit of the data (black circles). 
applications the LIBS technique seems to be mature enough for substituting or, at least, being complementary to other consolidated techniques. These applications will be discussed in the next sections.

\section{Applications of LIBS in industry}

The potential of laser-induced breakdown spectroscopy for online measurements in the energy production industry was immediately clear to the fathers of modern LIBS. The work of Hartford et $a l .{ }^{6}$ was published only two years after the publication of the two fundamental papers of Loree and Radziemski, ${ }^{16,17}$ where the acronym LIBS was officially introduced (the first 'LIBS' paper is commonly credited to Brech and Cross, ${ }^{\mathbf{1 8}}$ in 1962). The energy industry, in fact, is considered one of the major fields in which LIBS could become the election technique.

\subsection{Energy industry}

2.1.1 Fossil fueled power plants. The paper by Hartford et $a .^{6}{ }^{6}$ proposed LIBS as a diagnostic tool for quality control of the process of gasification of fossil fuels. The authors exploited the peculiarities of the LIBS technique for the diagnosis of trace impurities ( $\mathrm{Na}, \mathrm{K}$ and $\mathrm{S}$ ) on a coal gasifier, to monitor fossil energy processes. Coal has been, since then, one of the major lines of research for LIBS, especially in China, where coal power plants are the main sources of energy of the country. ${ }^{19}$ Bauer and Buckley ${ }^{20}$ in a recent paper mentioned coal analysis among the most promising industrial applications of LIBS. In their reviews on LIBS research on coal in China, Zhao et al. ${ }^{19}$ and Sheta et $a .^{21}$ presented several results obtained by Chinese researchers for the coal industry. Most of the papers available in the literature, however, are either very generic and do not give essential information about the practical application of LIBS at power plants, or report the results of laboratory analysis under highly simplified experimental conditions (i.e. homogeneous samples obtained by pressing powdered coal in the form of pellets $^{22-27}$ ) which can hardly be transferred to the real industrial application.

LIBS systems have been, in fact, proposed for on-line analysis of coal in power plants (see, for example, ref. 28 or 29). However, only a few real tests of LIBS in the coal industry were actually performed.

One of these was done in 2002 by Chadwick and Body ${ }^{30}$ for the determination of ash content in low-ash lignite. Ash content is one of the most important parameters in coal combustion, since an excessive content of ashes could produce fouling of the burner. It should be noted, however, that the authors determined the ash content starting from the elemental composition of the samples, using carbon as the internal standard. This is acceptable when similar types of coal are burnt in the power
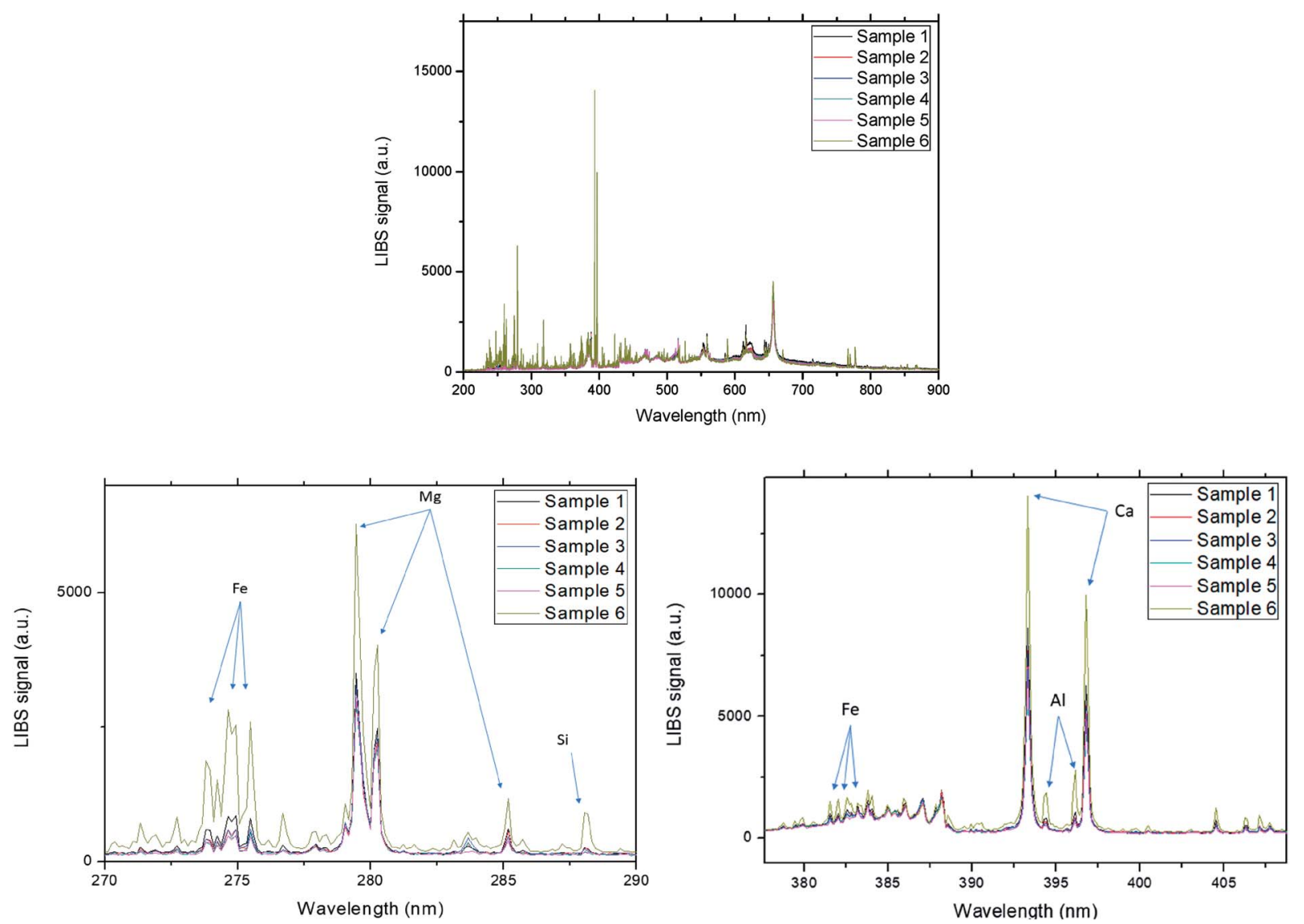

Fig. 2 Comparison of LIBS spectra from the same batch of coal. Top: full LIBS spectrum; bottom: details of the main elements' emission lines. 
plant but might introduce large errors in the general case (carbon content in coal could vary up to $25 \%$ depending on the origin and quality of the coal used). The authors also noted that the intrinsic inhomogeneity of the samples is the major obstacle to obtain the precise determination of the elemental composition of the coal, which is needed, according to their approach, for the determination of the ash content. A similar approach was used in coal power plants by Gaft et al. ${ }^{\mathbf{3 1}}$ for the on-line determination of ash content in coal. In fact, even for coal samples coming from the same batch, the LIBS spectra show a large variability in the intensity of the lines associated with the main elements that affect the ash content ( $\mathrm{Al}, \mathrm{Si}, \mathrm{Fe}$ and $\mathrm{Mg}$ ), reflecting the large variations in their concentration from sample to sample (see Fig. 2).

Legnaioli et $a .^{32}$ obtained a very good agreement between predicted and nominal values for ash content in coal using an artificial neural network method, preceded by spectral selection for outlier removal (see Fig. 3).

Another key parameter for monitoring and optimizing the efficiency of coal combustion in power plants is the Upper Calorific Value (UCP) of coal. ${ }^{33}$ As for the determination of ash content, several papers have been published reporting laboratory results on homogenized coal pellets ${ }^{25,34}$ which demonstrated the practical feasibility of LIBS analysis but, as in the case of ash content determination, do not transfer immediately to the on-line analysis of coal on the conveyor belt at power plants.

A critical point for coal analysis at the conveyor belt is given by the large changes in focus position that occur during the operation of the plant. Gaft et al. ${ }^{31}$ used an auto-focusing system of the laser beam on the surface of the samples; the system is very effective, although the use of delicate moving components in the industrial environment can be problematic. De Saro et $a l .{ }^{35}$ worked around the problem by picking a measurement point where the coal samples remain at a fixed distance with respect to the laser focusing lens. This approach is hardly

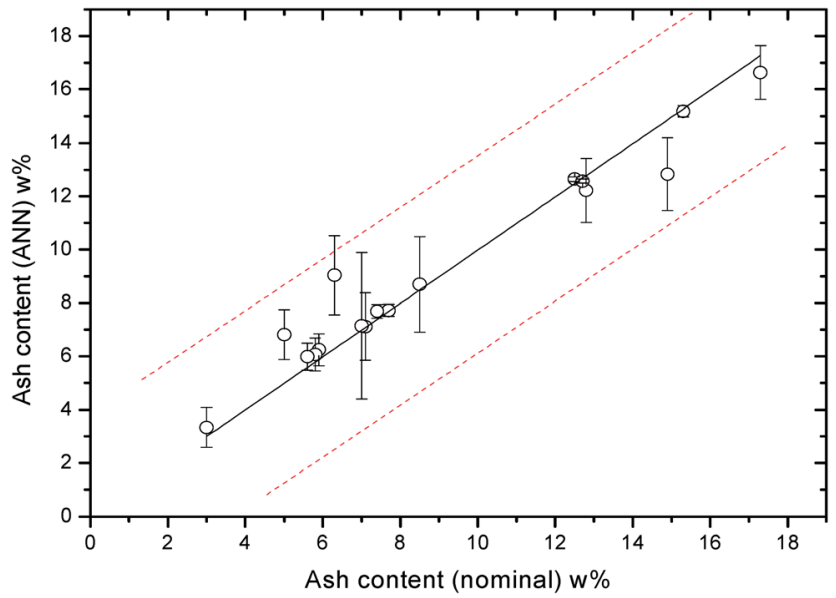

Fig. 3 Predicted values of ash content vs. nominal content for different coal types. The agreement is good (black line represents perfect agreement), with a maximum difference less than $4 \%$ (red lines). transferrable to different coal plants; therefore, it cannot be considered as a solution of the problem.

A promising method for avoiding sampling and treatment of the coal and managing the variations in the lens-to-sample distance at the conveyor belt has been recently proposed by Redoglio et al..$^{36}$ The method proposed by the authors allows, in principle, the measurement of the main parameters of coal (ash content and calorific value) without sampling by using a large depth of field (more than $10 \mathrm{~cm}$ ) LIBS system. A similar experimental setup has been realized and successfully tested by the authors of ref. 32 (see Fig. 4).

Also in this case, an artificial neural network can be set-up for calculating the UCP. However, the spectral regions to use as input of the ANN must be chosen carefully, corresponding to the emission lines of the elements actually affecting the output (upper calorific power). Several semi-empirical formulas exist, linking coal characteristics to the UCP. The Dulong formula ${ }^{33}$ links the UCV to the carbon, hydrogen, oxygen and sulfur content of coal; Mason-Gandhi formula ${ }^{37}$ does not use oxygen concentration, substituting this information with the ash content value. More complex, non-linear formulas have also been proposed. ${ }^{38}$

An alternative formula was obtained by Palleschi, Paganini and Masci (PPM), ${ }^{39}$ assuming a more general linear relationship

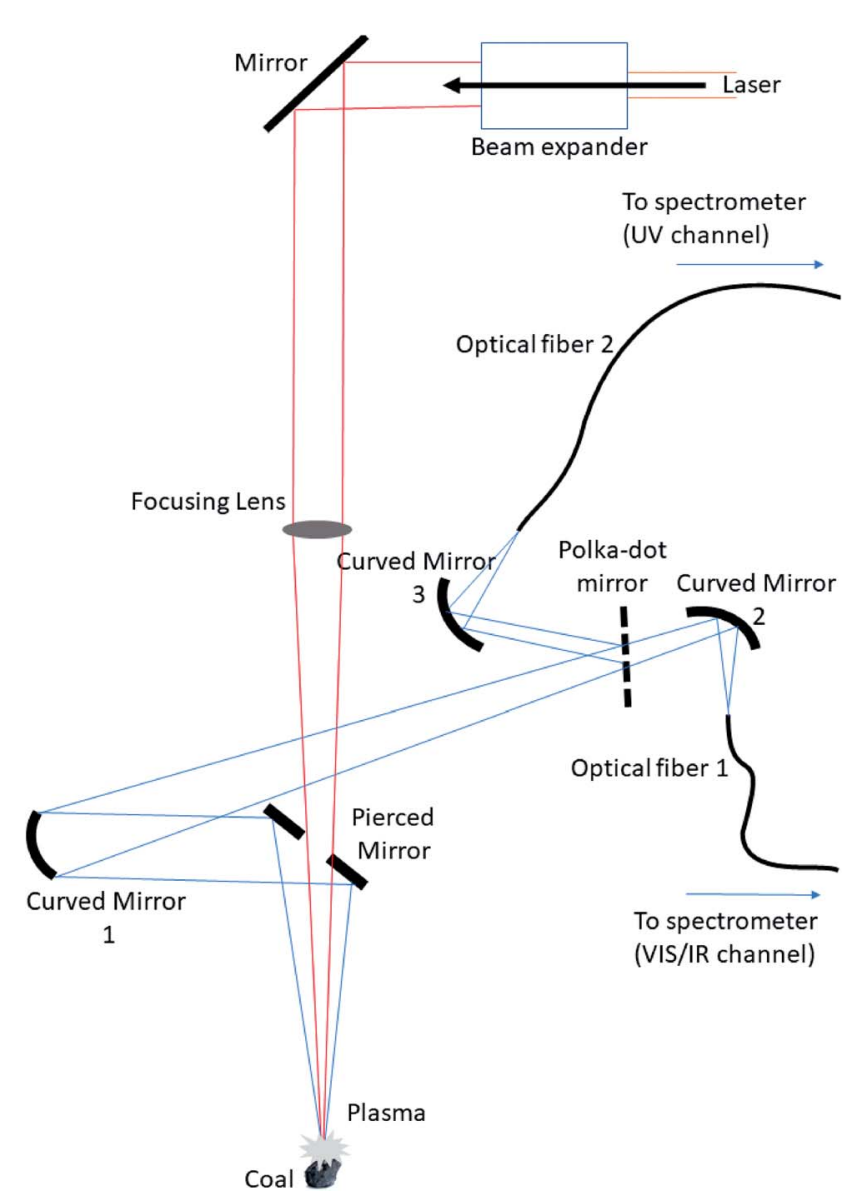

Fig. 4 Large depth of field double-pulse LIBS apparatus realized at the ALS Laboratory in Pisa. ${ }^{32}$ 
between UCP and the concentrations of carbon, hydrogen, sulfur, nitrogen and the ash content. The coefficients of the linear combination were obtained through a partial least squares analysis ${ }^{\mathbf{4 0}}$ applied to all the samples in a large database of over 4000 different types of coal. After that, the model was progressively simplified, removing the elements less correlated to the UCV. Palleschi, Paganini and Masci found that using just carbon and hydrogen concentration the PPM formula

$$
\mathrm{UCP}_{\mathrm{PPM}}=69.45 \mathrm{C}+224.3 \mathrm{H}+853.3
$$

reproduces well the experimental UCPs of the samples.

Based on this result, Palleschi, Paganini and Masci limited the spectral regions to be used as inputs in the ANN to the carbon and hydrogen lines, obtaining very good agreement between predicted UCP and nominal values, for the samples studied in ref. 32 (Fig. 5).

Recent applications of LIBS to oil shale have been proposed for discrimination from limestone by Paris et $a .^{\mathbf{4 1}}$ and for determination of the calorific power. ${ }^{42}$

LIBS was also used for in situ diagnosis of the products of combustion of oil-fired power plants in 2002 by Corsi et al., ${ }^{43}$ who demonstrated the possibility of performing remote LIBS analysis for the control of the emissions of fossil fueled power plants.

2.1.2 Nuclear industry. The possibility of using LIBS for the analysis of materials in the hostile environment of a nuclear power plant was discussed for the first time by Davies et al. in 1996. ${ }^{44}$ However, it was the UK firm Applied Photonics which pioneered the studies and application of LIBS to the nuclear industry. ${ }^{45,46}$ Following the same route, several applications of LIBS for the analysis of nuclear materials were reported in the past few years. Harilal et al. studied the space and temporal evolution of uranium LIBS spectra. ${ }^{47}$ Lang et $a l .{ }^{48}$ in 2018 used LIBS for the study of nuclear contaminated steel (304 stainless steel type; this material is often used in nuclear material reprocessing sites). The authors performed stratigraphic

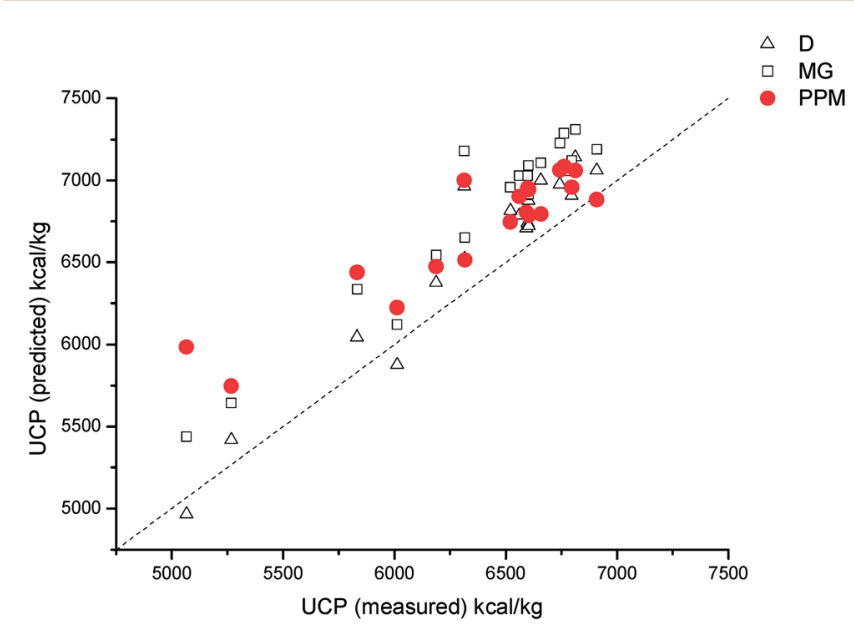

Fig. 5 Comparison between the Dulong (open triangles), MasonGandhi (open squares) and Palleschi-Paganini-Masci (red circles) formulas, for the coal samples analysed in the database. analysis to understand the penetration depth of ${ }^{90} \mathrm{Sr}$ and ${ }^{137} \mathrm{Cs}$ under the metal surface. They found that only $\mathrm{Sr}$ can be detected at realistic concentration; the depth profiles obtained, after optimization of the laser energy, were in very good agreement with glow-discharge-optical emission spectroscopy. LIBS was also used for the analysis of nuclear-grade graphite by Horsfall et al. $^{49}$ in 2019. The authors remarked that the discrimination by LIBS of nuclear grade graphite from other Cbased materials in nuclear waste can be plagued by errors in classification and proposed more robust statistical methods, along with the use of molecular carbon emission, for the analysis of waste which can be especially useful for decommissioning and waste management. A methodology for LIBS forensic analysis of nuclear materials has been recently proposed by Bhatt et al. ${ }^{50}$

A robotic LIBS system has been proposed for detecting the presence of chlorine-bearing salts on the surface of canisters used for dry storage of spent nuclear fuel. ${ }^{51}$

Of special interest is the application of a particular kind of LIBS analysis, called LAMIS, ${ }^{52}$ for remote analysis of uranium isotopes using femtosecond lasers. ${ }^{53}$ In LAMIS, the emissions associated with the transitions of simple molecules are studied, to enhance the isotopic spectral separation, which is typically very difficult to resolve in atomic emission. ${ }^{54-56}$

2.1.3 Solar energy industry. The first application of LIBS to solar cell analysis was proposed by Hidalgo et al. in $1996 .{ }^{57}$ The authors used the capability of the technique for performing indepth analysis for quality control of the titanium dioxide antireflection coating in solar cells. The same group also proposed the use of LIBS tomographic and surface mapping of carbon impurities in silicon. ${ }^{58}$ An application of LIBS which appears to be very interesting in the field of the solar cell industry is the analysis of thin film $\mathrm{CuIn}_{1-x} \mathrm{Ga}_{x} \mathrm{Se}_{2}$ (CIGS) solar cells. Kowalczyk et al. ${ }^{59}$ used LIBS for determining the concentration of sodium in CIGS cells. Similarly, Lee et al. ${ }^{\mathbf{6 0 - 6 2}}$ studied the absorption layer of CIGS cells, in terms of ablation and spectroscopic characteristics, for a rapid composition analysis of thin film solar cells. Diego-Vallejo et al. ${ }^{\mathbf{6 3 , 6 4}}$ studied the selective ablation of copper-indium-diselenide solar cells using LIBS coupled with artificial neural networks and classification methods. Choi et al. ${ }^{65,66}$ studied the effect of laser spot size and wavelength in LIBS analysis of CIGS. Kim et $a l .^{67,68}$ compared LIBS thin film and bulk analysis of $\mathrm{CuIn}_{1-x} \mathrm{Ga}_{x} \mathrm{Se}_{2}$, studying the influence of wavelength on LIBS measurement of thin film CIGS. In et al. ${ }^{69-72}$ focused their research on the improvement of selenium analysis and reproducibility of LIBS measurements of CIGS cells with the fluctuation of the experimental parameters and applied selfabsorption normalization to improve the reliability of the LIBS results; the conclusion of their work is that LIBS can be a viable technique for rapid quantitative analysis and depth profiling of CIGS thin solar cell films.

\subsection{Metal industry}

Many laboratory studies are reported in the LIBS literature, dealing with the analysis of metals and metallic alloys, ${ }^{73-77}$ 
which can be indirectly referred to industrial applications. Two reviews by Noll et al. outlined the major applications up to the date of their publication;,; ${ }^{3,7}$ new applications of LIBS in the metal industry have been presented and discussed in ref. 79. In the following, attention will be restricted to the applications of LIBS successfully demonstrated in the industrial environment, for process optimization and quality control. It should be considered, however, that the LIBS technique can be a valid alternative to spark OES for off-line analysis of metals, as demonstrated in many recent papers.

2.2.1 Steel industry. The economic importance of the steel industry has motivated many research studies aimed at the optimization of the production processes or quality control of the products. The LIBS technique is particularly suitable for the analysis of metals, and therefore many applications in the metallurgic industry (mainly steel and aluminum) have been proposed and tested in the past few decades. One of the first industrial applications of LIBS steel analysis was the on-line analysis of steel pipes for early detection of surface defects (the LIBSGRAIN project, funded by the European Commission $)^{80}$ (see Fig. 6). Aimoto et al. preformed (off-line) a similar analysis. ${ }^{81}$

In 2003, Kraushaar et al. made off-line analysis of slag samples from a steel plant $\mathrm{t}^{\mathrm{82}}$ to simulate the on-line analysis of molten steel. ${ }^{83}$ Gondal et al. ${ }^{84}$ studied by LIBS the possible presence of dangerous elements in waste slag from the steel industry. The authors analyzed the levels of contamination by cadmium, calcium, sulfur, magnesium, chromium, manganese, titanium, barium, phosphorus and silicon in slag samples and found very good agreement with the results of conventional chemical analysis. They concluded that LIBS can be effectively applied to rapid online analysis of iron slag waste.

The LACOMORE (laser-based continuous monitoring and resolution of steel grades in sequence casting machines) project, funded by the European Commission, has demonstrated the possibility of on-line control of the process of continuous steel casting. ${ }^{8,85-88}$ This would provide large potential saving by reducing the steel waste, through a careful control of the intermix region in passing from one steel grade to the other (Fig. 7).

The Canadian firm Tecnar is offering a LIBS system, named GalvaLIBS, for the analysis of molten metals, including steel. ${ }^{89}$

On-line depth profiling of Mg-coated galvanized steel on moving targets has been documented by Ruiz et al. ${ }^{90}$ LIBS has also been used for the analysis of surface coating on steel by
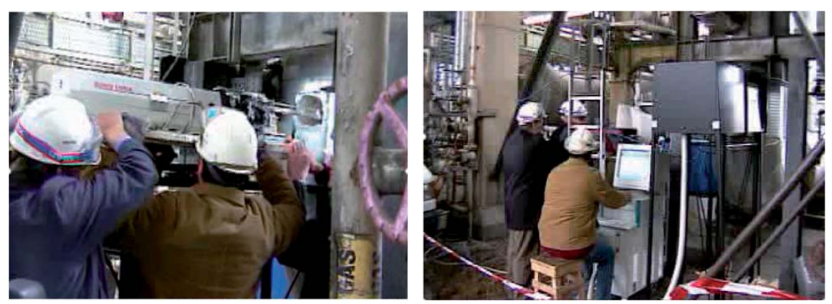

Fig. 6 LIBSGRAIN project: mounting of the laser at the plant for pipe analysis (left) and mapping of steel composition (right).

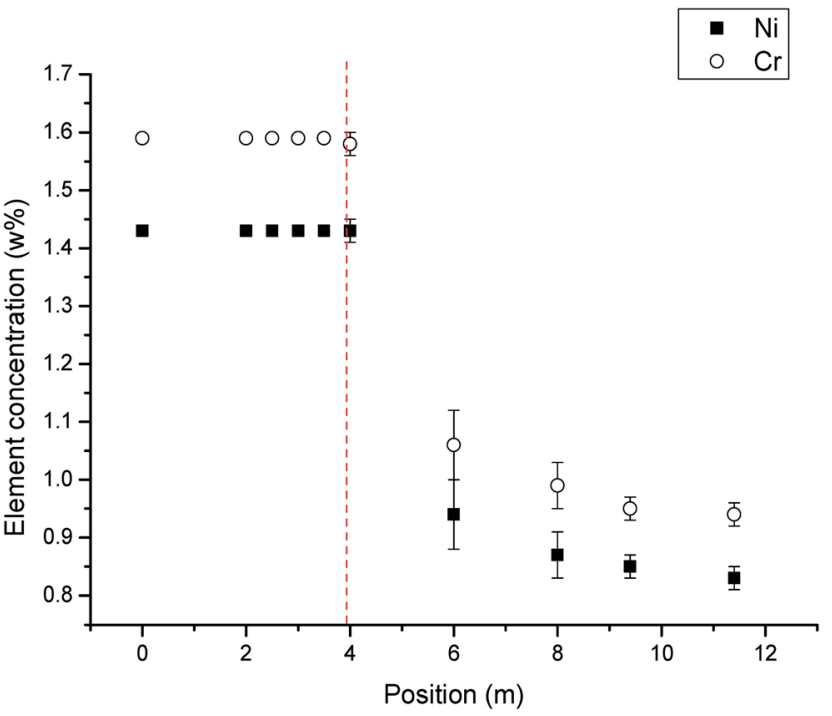

Fig. 7 LACOMORE project: change in $\mathrm{Ni}$ and $\mathrm{Cr}$ concentration measured by double pulse LIBS in continuous casting of steel (data from ref. 85).

Balzer et al. (Al coating ${ }^{91}$ and $\mathrm{Zn}$ coating ${ }^{92}$ ), Nagy et al. (Al-Ni coating) ${ }^{93}$ and Pacher et al. (Ni-Co coating). ${ }^{94}$

Elfaham et al. ${ }^{95}$ used LIBS for evaluating the surface hardness of steel samples, using the ratio between the calcium ion and neutral lines (Ca II/Ca I) and compared the results with the Vickers mechanical method. The authors found a very good agreement between the two measurements, once selfabsorption corrections are applied to the LIBS line intensities. The authors also stressed the importance of self-absorption correction for a precise quantitative analysis of steel composition.

The use of hand-held LIBS instrumentation ${ }^{96}$ as an alternative to laboratory measurements ${ }^{97-99}$ has also been proposed for steel analysis.

Girón et al. ${ }^{100}$ used LIBS for monitoring and characterizing dangerous particulates in the hostile environment of the steel industry. The authors used a standoff LIBS system deployed at a steel factory during the LACOMORE measurements for the analysis of particulates in the ambient air. The power density of the laser beam at the focus was high enough to produce air breakdown; Giron et al. collected the spectra at a fixed repetition rate of the laser, obtaining spectra corresponding to pure air breakdown (only elements from the atmosphere were visible) and other spectra characterized by line emission of elements from the particulates produced in the industrial process $(\mathrm{Ca}, \mathrm{Al}, \mathrm{Ti}$, and $\mathrm{Li}$ from casting powder, $\mathrm{Cr}$ from the steel). Using conditional analysis, the authors were able to give an estimate of the concentration of the particulates in the working environment and noted that the concentration of dangerous elements, considering the relatively low sampling rate of the technique, might be considered as significant.

2.2.2 Aluminum industry. Aluminum has been studied by LIBS since the early stages of development of the technique, because of the relative simplicity of its emission spectrum and 
the importance of this material in the metal industry. ${ }^{\mathbf{1 0 1 - 1 0 5}}$ Among the most interesting industrial applications of LIBS is the one involving the on-line analysis of molten aluminum..$^{\mathbf{8 9}, 106}$

A commercial LIBS system for at-the-line and on-line liquid aluminum analysis has been developed by the DTE firm, in Iceland. ${ }^{107}$

2.2.3 Other metals. Copper-based alloys have been studied extensively by LIBS, ${ }^{\mathbf{1 0 8 - 1 1 1}}$ for the same motivation as for aluminum alloys. Moreover, copper-based alloys are often studied in the framework of cultural heritage or archaeological studies, ${ }^{\mathbf{1 1 2}}$ a field where the capabilities of LIBS are particularly appreciated. The industrial applications of LIBS on copperbased alloys, in contrast, are not particularly numerous. Among the few, one that is worthy of mention is the use of LIBS for determining the composition of industrial copper concentrates proposed by Łazarek et al. ${ }^{113}$

Zinc-alloys (Zamac) were analyzed using LIBS by Messaoud et al. ${ }^{114}$

\subsection{Pharmaceutical industry}

The applications of LIBS for characterization and quality control in the pharmaceutical industry have been the subject of several papers at the beginning of this century. ${ }^{115-117}$ As a matter of fact, one of the first commercial LIBS instruments, called PharmaLIBS 250, was realized for quality control of pharmaceutical tablets by PharmaLaser Inc., a Canadian firm supported by the Industrial Material Institute (IMI) of the National Research Council of Canada (NRCC). Good performances of the instruments for assessing the homogeneity of tablets' coating were reported by Mowery et al. ${ }^{115}$ Other applications of the instruments were discussed by St Onge et al. in ref. 116 and 117. PharmaLaser went out of the market in the first decade of this century, but the research on pharmaceutical applications of LIBS continued. LIBS was used for the characterization of film coatings by Madamba et al. ${ }^{118}$ The authors successfully evaluated by LIBS the thickness, homogeneity and composition of pharmaceutical tablet coatings, demonstrating how these parameters can be correlated to the photostability of the coating. Arantes de Carvalho et al. ${ }^{\mathbf{1 1 9}}$ studied by LIBS the macro and micronutrients in pharmaceutical tablets, arriving at the conclusion that LIBS is a viable technique for the analysis of multielement tablets for the determination of $\mathrm{Ca}, \mathrm{Cu}$, $\mathrm{Fe}, \mathrm{Mg}, \mathrm{Mn}, \mathrm{P}$ and $\mathrm{Zn}$. Myakalwar et al. ${ }^{\mathbf{1 2 0}}$ explored the effectiveness of multivariate chemometric analysis for the study of pharmaceutical tablets and for their classification, concluding that LIBS can be effectively used for quality control and detection of possible counterfeits. The peculiar characteristics of LIBS for performing in-depth analysis were exploited by Zou et al. ${ }^{\mathbf{1 2 1}}$ which demonstrated the possibility of obtaining 3D chemical images of pharmaceutical tablets, with a depth resolution of about $2.6 \mu \mathrm{m}$, which can be usefully exploited for determining coating thickness and uniformity, as well as the presence of contaminants, evidenced by their peculiar elemental composition.

The problem of characterization of pharmaceutical tablet coatings has been recently discussed by Yang et al., ${ }^{\mathbf{1 2 2}}$ who compared different techniques, including LIBS, for quality control of the products.
An alternative approach to standard LIBS analysis was proposed by Yang et al., ${ }^{123}$ who characterized the molecular emission signal produced by the laser-induced plasma in the mid- and long wave infrared region (4-12 $\mu \mathrm{m})$, demonstrating a strong correlation between the LIBS signal and the results of conventional infrared molecular spectroscopy of the organic compounds present in pharmaceutical products.

In recent years, LIBS has been used for analysis and quality control of traditional medicinal products. ${ }^{\mathbf{1 2 4 - 1 2 6}}$

\subsection{Building industry}

The LIBS technique has been proposed in the building industry mainly for quality control of concrete structures. Back in 1996 Pakhomov et al. ${ }^{\mathbf{1 2 7}}$ used LIBS for detecting lead in concrete. Other elements often studied for their importance in concrete structures are carbon, ${ }^{\mathbf{1 2 8}}$ sulfur ${ }^{\mathbf{1 2 8 - 1 3 2}}$ and, most of all, chlorine. ${ }^{128,132-140}$ Sulfur and chlorine are elements not easily detectable by conventional LIBS analysis. Gehlen et al. ${ }^{\mathbf{1 3 3}}$ optimized the laboratory conditions for chlorine analysis on concrete drill cores, finding optimal detection limits with the $\mathrm{Cl}$ UV line at $134.72 \mathrm{~nm}$ and working at an environmental pressure of 60 mbar. The authors also tried collinear double-pulse LIBS, without obtaining any improvement of the detection limits. One of the most exhaustive reports on the detection of chlorine in concrete was delivered by Omenetto et al. ${ }^{141}$ in the framework of a research grant assigned to the University of Florida, Gainesville, FL, USA, by the Florida Department of Transportation. The authors tested several experimental configurations for $\mathrm{Cl}$ analysis in concrete and mortars; the best results were obtained by analyzing the ionic $\mathrm{Cl}$ line at $479.454 \mathrm{~nm}$ in a He atmosphere. Similar results were obtained using a LAMIS $^{52}$ approach, analyzing the $\mathrm{CaCl}$ molecular band at $593.5 \mathrm{~nm}$. As already noted in ref. 133, the use of double pulse (in this case, in the orthogonal configuration) did not improve the detection limits obtained using single pulse LIBS and LAMIS (LOD $\cong 0.05 \mathrm{wt} \%$ ).

Use of LIBS for detection of asbestos in construction materials was also proposed by Caneve et al. in $2005 .^{\mathbf{1 4 2}}$

\subsection{Waste management industry}

The possibility of LIBS to operate remotely on fast moving objects has led to several applications of the technique in the waste management industry. One of the first proposals of LIBS in the waste and recycling industry was aimed at identification and sorting of plastic substances; ${ }^{\mathbf{1 4 3 - 1 4 6}}$ more recently, a combination of LIBS and Raman technique has been demonstrated to be very effective for this purpose. ${ }^{147}$ Other applications have demonstrated the effectiveness of LIBS for the control of the process of recovering precious metals from electronic wastes. ${ }^{\mathbf{1 4 8 , 1 4 9}}$ Similarly, the determination by LIBS of the fraction of plastic waste from mobile phone scraps has been discussed by Camara Costa $^{150}$ and Aquino. ${ }^{151}$

Another important application of LIBS is related to the European Commission project SHREDDERSORT, aimed at the efficient sorting of non-ferrous metallic scraps from the automotive industry ${ }^{152}$ (see Fig. 8). 


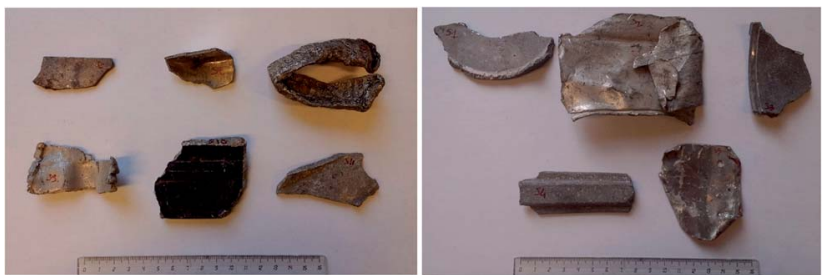

Fig. 8 SHREDDERSORT project: non-ferrous metallic scraps from the automotive industry.

Secopta Analytics GMBH, a German firm, has produced a commercial instrument for sorting aluminum scraps. ${ }^{153}$ Based on similar principles, the REFRASORT project, funded by the European Commission, has developed a LIBS sorting procedure for refractory wastes..$^{154}$

The feasibility of using LIBS for the analysis of spent batteries has been demonstrated by Peng et al. ${ }^{155}$

\subsection{Mining industry}

The LIBS technique has been extensively used for the analysis of mining products for several years..$^{156-162}$ Gaft et al. ${ }^{163}$ were among the first to sense the potential of LIBS for on-line geological analysis. An industrial analyser was proposed in 2014; ${ }^{\mathbf{1 6 4}}$ the recent development of LIBS instrumentation for fast elemental imaging has opened the way for 3D elemental analysis of geological materials. ${ }^{165-167}$

ELEMISSION, a Canadian firm, has developed a commercial instrument for geological analysis ${ }^{168}$ which is able to obtain elemental LIBS images at $\mathrm{kHz}$ rate. ${ }^{169}$

\subsection{Food and feed industry}

Another important application of LIBS is the quality control and adulteration detection in the food and feed industry. Defects, contamination and adulteration, as well as the micro-nutrient content of several foods have been studied by LIBS. An extensive review of the capabilities and limitations of LIBS in food analysis has been recently published by Sezer $e t$ al. ${ }^{170}$

Silva et al. used LIBS for predicting the amount of defective beans in coffee blends. ${ }^{171}$ Khalil et al. ${ }^{172}$ applied LIBS for the detection of micro-toxic elements in commercial coffee brands, using double-pulse LIBS. Sezer et al. used LIBS for detecting possible adulteration of Coffea arabica, by fraudulent addition of wheat, corn and chickpea, ${ }^{173}$ as well as milk adulteration with wheat ${ }^{174}$ (see also Bilge et al. ${ }^{175}$ and Moncayo et al. ${ }^{176}$ ). AbdelSalam et al. ${ }^{177}$ used LIBS for quality assessment of commercial infant formulas vs. maternal milk. Similarly, Dos Santos et al. ${ }^{178}$ studied the optimal calibration conditions for the determination of $\mathrm{Ca}, \mathrm{Mg}$ and $\mathrm{K}$ in powdered milk and dietary tablets. Ferreira et al. ${ }^{179}$ used LIBS for the determination of $\mathrm{Ca}$ in breakfast cereals. Gondal et al. ${ }^{180}$ studied by LIBS the composition of tea samples, finding a good agreement with ICP-MS measurements. Also Zhang et al. ${ }^{181}$ performed LIBS analysis on Chinese tea leaves, with the purpose of optimizing the optimal spectral lines for classification and quality control. Se et al. ${ }^{182}$ used chemometric analysis for the determination of $\mathrm{Ca}$,
$\mathrm{Mg}$ and Na content in honey. The challenges for application of LIBS in agricultural studies were discussed in a recent review by Peng et al. ${ }^{183}$ Eum et al. ${ }^{184}$ discussed the combined use of LIBS and near-infrared spectroscopy for the identification of the geographical origin of vegetable samples. Atta et al. used LIBS for the quantification of micro-nutrients (zinc, iron) in wheat, ${ }^{185}$ noticing that LIBS analysis can be useful for growers in selecting the wheat genotypes richer in these micronutrients. Sezer et al. ${ }^{186}$ proposed LIBS as a rapid, reliable, and environmentally friendly alternative to standard protein assay methods; the authors successfully correlated the nitrogen concentration with the protein content in wheat flour and whole meal. Shen et al. ${ }^{187}$ proposed LIBS for rapid determination of possible cadmium contamination in lettuce.

Sezer et al. ${ }^{188}$ used LIBS for the identification and quantification of LiNa, a toxic salt substitute in meatballs, demonstrating a limit of detection for Li of about $4.5 \mathrm{ppm}$. Bilge et al. ${ }^{189}$ and Chu et al. ${ }^{190}$ used LIBS for the identification of different meat species; Velioglu et al. ${ }^{191}$ exploited these results for the identification of possible offal adulteration in beef. A similar analysis was done by Casado-Gavalda et al. ${ }^{192}$ using copper content in beef as a possible indicator of offal adulteration. Dixit et al. ${ }^{193,194}$ proposed the use of LIBS elemental imaging for salt diffusion in brining of meat, and demonstrated the possibility of LIBS quantification of rubidium as trace element in beef.

The feasibility of on-line LIBS control in the poultry meat production industry has been discussed by Andersen. ${ }^{195}$

\section{Conclusion}

Several considerations can be derived from the analysis of recent literature on the industrial applications of LIBS: the traditional fields of application of LIBS seem to attract strong interest from the scientific community. Several commercial LIBS instruments have been proposed for on-line analysis of materials in the metallurgic industry, and special attention is given to the possibility of on-line control of the production process (continuous casting of steel, analysis on liquid metals, etc.). Also in the field of energy production, the unique advantages of LIBS forecast an imminent transfer of the laboratory prototypes to the real industrial environment, especially for online analysis of coal. LIBS is also very promising for its application in recycling (plastic and metallic wastes, mainly) and mining industries. Other industrial applications of LIBS, such as the ones in pharmaceutical and food industries, seem to be less mature, mainly because of the complexity of the products to be analysed, which are probably better dealt with molecular techniques such as infrared spectroscopy, Raman, etc. The rapid technological developments in the field of compact laser systems and spectrographs, as well as the drop in the cost of these instruments, are expected to greatly contribute to the implementation of LIBS in the industrial sector.

\section{Conflicts of interest}

There are not conflicts to declare. 


\section{References}

1 A. W. Miziolek, V. Palleschi and I. Schechter, Laser Induced Breakdown Spectroscopy (LIBS): Fundamentals and Applications, 2006, DOI: 10.1017/cbo9780511541261.

2 Y. Deguchi and Z. Wang, Industrial Applications of LaserInduced Breakdown Spectroscopy, in Plasma Sci. Technol. - Prog. Phys. States Chem. React., InTech, 2016, DOI: 10.5772/61915.

3 R. Noll, C. Fricke-Begemann, S. Connemann, C. Meinhardt and V. Sturm, LIBS analyses for industrial applications - an overview of developments from 2014 to 2018, J. Anal. At. Spectrom., 2018, 33, 945-956, DOI: 10.1039/c8ja00076j.

4 R. Noll, V. Sturm, M. Stepputat, A. Whitehouse, J. Young and P. Evans, Industrial applications of LIBS, in LaserInduced Break. Spectrosc., ed. A. W. Miziolek, V. Palleschi and I. Schechter, Cambridge University Press, Cambridge, 2006, pp. 400-439, DOI: 10.1017/cbo9780511541261.012.

5 D. A. Cremers and R. C. Chinni, Laser-Induced Breakdown Spectroscopy-Capabilities and Limitations, Appl. Spectrosc. Rev., 2009, 44, 457-506, DOI: 10.1080/ 05704920903058755.

6 A. Hartford Jr, D. A. Cremers, T. R. Loree, G. P. Quigley, L. J. Radziemski and D. J. Taylor, in Optical Instrumentation for On-line Analysis of Chemical Processes, ed. R. A. Carella and F. M. Zweibaum, 1983, pp. 92-96, DOI: $10.1117 / 12.935786$.

7 G. Cristoforetti, S. Legnaioli, V. Palleschi, L. Pardini, A. Salvetti and E. Tognoni, Modi: a new mobile instrument for in situ standard-less LIBS analysis of Cultural Heritage, Proc. SPIE 5857, Optical Methods for Arts and Archaeology, 12 August 2005, p. 58570G, DOI: 10.1117/ 12:624161.

8 J. Ruiz, T. Delgado, L. M. Cabalín and J. J. Laserna, At-line monitoring of continuous casting sequences of steel using discriminant function analysis and dual-pulse laserinduced breakdown spectroscopy, J. Anal. At. Spectrom., 2017, 32, 1119-1128, DOI: 10.1039/c7ja00093f.

9 S. Legnaioli, G. Lorenzetti, L. Pardini, G. H. Cavalcanti and V. Palleschi, Double and Multiple Pulse LIBS Techniques, 2014, DOI: 10.1007/978-3-642-45085-3_5.

10 T. Vance, N. Reljin, A. Lazarevic, D. Pokrajac, V. Kecman, N. Melikechi, A. Marcano, Y. Markushin and S. McDaniel, Classification of LIBS protein spectra using support vector machines and adaptive local hyperplanes, in 2010 Int. Jt. Conf. Neural Networks, IEEE, 2010, pp. 1-7, DOI: 10.1109/ ijcnn.2010.5596575.

11 D. Pokrajac, T. Vance, A. Lazarević, A. Marcano, Y. Markushin, N. Melikechi and N. Reljin, Performance of multilayer perceptrons for classification of LIBS protein spectra, in 10th Symp. Neural Netw. Appl. Electr. Eng. NEUREL-2010 - Proc., 2010, pp. 171-174, DOI: 10.1109/ neurel.2010.5644078.

12 T. Vance, N. Reljin, A. Lazarevic, D. Pokrajac, V. Kecman, N. Melikechi, A. Marcano, Y. Markushin and S. McDaniel, Classification of LIBS protein spectra using support vector machines and adaptive local hyperplanes, Proceedings of 2010 IEEE World Congress on Computational Intelligence, Barcelona, Spain, 2010, pp. 1-7, DOI: 10.1109/ IJCNN.2010.5596.575.

13 E. D'Andrea, S. Pagnotta, E. Grifoni, S. Legnaioli, G. Lorenzetti, V. Palleschi and B. Lazzerini, A hybrid calibration-free/artificial neural networks approach to the quantitative analysis of LIBS spectra, Appl. Phys. B: Lasers Opt., 2015, 118, 353-360, DOI: 10.1007/s00340-014-5990-z.

14 M. Baudelet, Laser Spectroscopy for Sensing: Fundamentals, Techniques and Applications, Woodhead Publishing, 2014.

15 V. Palleschi, If laser-induced breakdown spectroscopy was a brand: some market considerations, Spectrosc. Eur., 2017, 29, 6-9.

16 T. R. Loree and L. J. Radziemski, Laser-induced breakdown spectroscopy: time-integrated applications, Plasma Chem. Plasma Process., 1981, 1, 271-279, DOI: 10.1007/ bf00568835.

17 L. J. Radziemski and T. R. Loree, Laser-induced breakdown spectroscopy: time-resolved spectrochemical applications, Plasma Chem. Plasma Process., 1981, 1, 281-293, DOI: 10.1007/bf00568836.

18 F. Brech and L. Cross, Optical Microemission Stimulated by a Ruby MASER, Appl. Spectrosc., 1962, 16, 59.

19 Y. Zhao, L. Zhang, S.-X. Zhao, Y.-F. Li, Y. Gong, L. Dong, W.-G. Ma, W.-B. Yin, S.-C. Yao, J.-D. Lu, L.-T. Xiao and S.-T. Jia, Review of methodological and experimental LIBS techniques for coal analysis and their application in power plants in China, Frontiers of Physics, 2016, 11, 114211, DOI: 10.1007/s11467-016-0600-7.

20 A. J. R. R. Bauer and S. G. Buckley, Novel Applications of Laser-Induced Breakdown Spectroscopy, Appl. Spectrosc., 2017, 71, 553-566, DOI: 10.1177/0003702817691527.

21 S. Sheta, M. S. Afgan, Z. Hou, S.-C. Yao, L. Zhang, Z. Li and Z. Wang, Coal analysis by laser-induced breakdown spectroscopy: a tutorial review, J. Anal. At. Spectrom., 2019, 34, 1047-1082, DOI: 10.1039/c9ja00016j.

22 Z. Hou, Z. Wang, T. Yuan, J. Liu, Z. Li and W. Ni, A hybrid quantification model and its application for coal analysis using laser induced breakdown spectroscopy, J. Anal. At. Spectrom., 2016, 31, 722-736, DOI: 10.1039/c5ja00475f.

23 L. Zhang, Y. Gong, Y. Li, X. Wang, J. Fan, L. Dong, W. Ma, W. Yin and S. Jia, Development of a coal quality analyzer for application to power plants based on laser-induced breakdown spectroscopy, Spectrochim. Acta, Part B, 2015, 113, 167-173, DOI: 10.1016/j.sab.2015.09.021.

24 T. Yuan, Z. Wang, Z. Li, W. Ni and J. Liu, A partial least squares and wavelet-transform hybrid model to analyze carbon content in coal using laser-induced breakdown spectroscopy, Anal. Chim. Acta, 2014, 807, 29-35, DOI: 10.1016/j.aca.2013.11.027.

25 W. Li, J. Lu, M. Dong, S. Lu, J. Yu, S. Li, J. Huang and J. Liu, Quantitative Analysis of Calorific Value of Coal Based on Spectral Preprocessing by Laser-Induced Breakdown Spectroscopy (LIBS), Energy Fuels, 2018, 32, 24-32, DOI: 10.1021/acs.energyfuels.7b01718. 
26 C. E. Romero, R. De Saro, J. Craparo, A. Weisberg, R. Moreno and Z. Yao, Laser-Induced Breakdown Spectroscopy for Coal Characterization and Assessing Slagging Propensity, Energy Fuels, 2010, 24, 510-517, DOI: 10.1021/ef900873w.

27 S. Yao, J. Lu, M. Dong, K. Chen, J. Li and J. Li, Extracting Coal Ash Content from Laser-Induced Breakdown Spectroscopy (LIBS) Spectra by Multivariate Analysis, Appl. Spectrosc., 2011, 65, 1197-1201, DOI: 10.1366/10-06190.

28 S. Yao, J. Mo, J. Zhao, Y. Li, X. Zhang, W. Lu and Z. Lu, Development of a Rapid Coal Analyzer Using LaserInduced Breakdown Spectroscopy (LIBS), Appl. Spectrosc., 2018, 72, 1225-1233, DOI: 10.1177/0003702818772856.

29 W. Yin, L. Zhang, L. Dong, W. Ma and S. Jia, Design of a Laser-Induced Breakdown Spectroscopy System for OnLine Quality Analysis of Pulverized Coal in Power Plants, Appl. Spectrosc., 2009, 63, 865-872, DOI: 10.1366/ 000370209788964458.

30 B. L. Chadwick and D. Body, Development and Commercial Evaluation of Laser-Induced Breakdown Spectroscopy Chemical Analysis Technology in the Coal Power Generation Industry, Appl. Spectrosc., 2002, 56, 70-74, DOI: 10.1366/0003702021954232.

31 M. Gaft, E. Dvir, H. Modiano and U. Schone, Laser Induced Breakdown Spectroscopy Machine for Online Ash Analyses in Coal, Spectrochim. Acta, Part B, 2008, 63, 1177-1182, DOI: 10.1016/j.sab.2008.06.007.

32 S. Legnaioli, B. Campanella, S. Pagnotta, F. Poggialini and V. Palleschi, Determination of Ash Content of coal by Laser-Induced Breakdown Spectroscopy, Spectrochim. Acta, Part B, 2019, 155, 123-126, DOI: 10.1016/j.sab.2019.03.012.

33 W. A. Selvig and F. H. Gibson, Calorific Value of Coal, in Chem. Coal Util., ed. H. H. Lowry, John Wiley, New York, 1947, pp. 138-141.

34 Z. Lu, J. Mo, S. Yao, J. Zhao and J. Lu, Rapid Determination of the Gross Calorific Value of Coal Using Laser-Induced Breakdown Spectroscopy Coupled with Artificial Neural Networks and Genetic Algorithm, Energy Fuels, 2017, 31, 3849-3855, DOI: 10.1021/acs.energyfuels.7b00025.

35 C. E. Romero and R. De Saro, in LIBS Analysis for Coal, 2014, pp. 511-529. DOI: 10.1007/978-3-642-45085-3_19.

36 D. Redoglio, E. Golinelli, S. Musazzi, U. Perini and F. Barberis, A large depth of field LIBS measuring system for elemental analysis of moving samples of raw coal, Spectrochim. Acta, Part B, 2016, 116, 46-50. https:// biblioproxy.cnr.it:2114/science/article/pii/

S0584854715002797?via\%3Dihub, accessed November 1, 2018.

37 D. M. Mason and K. N. Gandhi, Formulas for calculating the calorific value of coal and coal chars: development, tests, and uses, Fuel Process. Technol., 1983, 7, 11-22, DOI: 10.1016/0378-3820(83)90022-x.

38 F. Rafezi, E. Jorjani and S. Karimi, Adaptive Neuro-Fuzzy Inference System Prediction of Calorific Value Based on the Analysis of U.S. Coals, in Artif. Neural Networks - Ind. Control Eng. Appl., InTech, 2011, DOI: 10.5772/15793.
39 V. Palleschi, E. Paganini and S. Masci, The ONLICOAL Project - Final Report, 2017.

40 S. Wold, M. Sjöström and L. Eriksson, PLS-regression: a basic tool of chemometrics, Chemom. Intell. Lab. Syst., 2001, 58, 109-130, DOI: 10.1016/S0169-7439(01)00155-1.

41 P. Paris, K. Piip, A. Lepp, A. Lissovski, M. Aints and M. Laan, Discrimination of moist oil shale and limestone using laser induced breakdown spectroscopy, Spectrochim. Acta, Part B, 2015, 107, 61-66, DOI: 10.1016/j.sab.2015.02.017.

42 M. Aints, P. Paris, M. Laan, K. Piip, H. Riisalu and I. Tufail, Determination of Heating Value of Estonian Oil Shale by Laser-Induced Breakdown Spectroscopy, J. Spectrosc., 2018, 2018, 1-10, DOI: 10.1155/2018/4605925.

43 M. Corsi, V. Palleschi, A. Salvetti and E. Tognoni, Calibration free laser induced plasma spectroscopy: a new method for combustion products analysis, Clean Air, 2002, 3, 69-79, DOI: 10.1080/15614410211845.

44 C. Davies, H. Telle and A. Williams, Remote in situ analytical spectroscopy and its applications in the nuclear industry, Fresenius. J. Anal. Chem., 1996, 355, 895-899, DOI: $10.1007 / \mathrm{s} 0021663550895$.

45 A. I. Whitehouse, J. Young, I. M. Botheroyd, S. Lawson, C. P. Evans and J. Wright, Remote material analysis of nuclear power station steam generator tubes by laserinduced breakdown spectroscopy, Spectrochim. Acta, Part B, 2001, 56, 821-830, DOI: 10.1016/s0584-8547(01)00232-4.

46 S. Lawson, P. Evans, A. I. Whitehouse, J. Wright and J. Young, Spying in hostile territory, Mater. World, 2000, 8, 13-15.

47 S. S. S. Harilal, P. K. K. Diwakar, N. L. L. LaHaye and M. C. C. Phillips, Spatio-temporal evolution of uranium emission in laser-produced plasmas, Spectrochim. Acta, Part B, 2015, 111, 1-7, DOI: 10.1016/j.sab.2015.06.003.

48 A. Lang, D. Engelberg, N. T. Smith, D. Trivedi, O. Horsfall, A. Banford, P. A. Martin, P. Coffey, W. R. Bower, C. Walther, M. Weiß, H. Bosco, A. Jenkins and G. T. W. Law, Analysis of contaminated nuclear plant steel by laser-induced breakdown spectroscopy, J. Hazard. Mater., 2018, 345, 114-122, DOI: 10.1016/ j.jhazmat.2017.10.064.

49 J. P. O. Horsfall, D. Trivedi, N. T. Smith, P. A. Martin, P. Coffey, S. Tournier, A. Banford, L. Li, D. Whitehead, A. Lang and G. T. W. Law, A new analysis workflow for discrimination of nuclear grade graphite using laserinduced breakdown spectroscopy, J. Environ. Radioact., 2019, 199-200, 45-57, DOI: 10.1016/j.jenvrad.2019.01.004.

50 B. Bhatt, K. Hudson Angeyo and A. Dehayem-Kamadjeu, LIBS development methodology for forensic nuclear materials analysis, Anal. Methods, 2018, 10, 791-798, DOI: 10.1039/c7ay02520c.

51 C. J. Lissenden, S. Choi, H. Cho, A. Motta, K. Hartig, X. Xiao, S. Le Berre, S. Brennan, K. Reichard, R. Leary, B. McNelly and I. Jovanovic, Toward Robotic Inspection of Dry Storage Casks for Spent Nuclear Fuel, J. Pressure Vessel Technol., 2017, 139, 031602, DOI: 10.1115/1.4035788.

52 R. E. Russo, A. A. Bol'shakov, X. Mao, C. P. McKay, D. L. Perry and O. Sorkhabi, Laser Ablation Molecular 
Isotopic Spectrometry, Spectrochim. Acta, Part B, 2011, 66, 99-104, DOI: 10.1016/j.sab.2011.01.007.

53 K. C. Hartig, I. Ghebregziabher and I. Jovanovic, Standoff Detection of Uranium and its Isotopes by Femtosecond Filament Laser Ablation Molecular Isotopic Spectrometry, Sci. Rep., 2017, 7, 43852, DOI: 10.1038/srep43852.

54 A. D'Ulivo, M. Onor, E. Pitzalis, R. Spiniello, L. Lampugnani, G. Cristoforetti, S. Legnaioli, V. Palleschi, A. Salvetti and E. Tognoni, Determination of the deuterium/hydrogen ratio in gas reaction products by laser-induced breakdown spectroscopy, Spectrochim. Acta, Part B, 2006, 61, 797-802, DOI: 10.1016/j.sab.2006.06.001.

55 J. Karhunen, A. Hakola, J. Likonen, A. Lissovski, P. Paris, M. Laan, K. Piip, C. Porosnicu, C. P. Lungu and K. Sugiyama, Development of laser-induced breakdown spectroscopy for analyzing deposited layers in ITER, Phys. Scr., 2014, T159, 014067, DOI: 10.1088/0031-8949/2014/ $\mathrm{t} 159 / 014067$.

56 F. R. Doucet, G. Lithgow, R. Kosierb, P. Bouchard and M. Sabsabi, Determination of isotope ratios using laserinduced breakdown spectroscopy in ambient air at atmospheric pressure for nuclear forensics, J. Anal. At. Spectrom., 2011, 26, 536-541, DOI: 10.1039/c0ja00199f.

57 M. Hidalgo, F. Martin and J. J. Laserna, Laser-induced breakdown spectrometry of titanium dioxide antireflection coatings in photovoltaic cells, Anal. Chem., 1996, 68, 1095-1100.

58 D. Romero and J. J. Laserna, Surface and tomographic distribution of carbon impurities in photonic-grade silicon using laser-induced breakdown spectrometry, $J$. Anal. At. Spectrom., 1998, 13, 557-560, DOI: 10.1039/ a707783a.

59 J. M. D. Kowalczyk, J. Perkins, J. Kaneshiro, N. Gaillard, Y. Chang, A. DeAngelis, S. A. Mallory, D. Bates and E. Miller, Measurement of the sodium concentration in CIGS solar cells via laser induced breakdown spectroscopy, in 2010 35th IEEE Photovolt. Spec. Conf., IEEE, 2010, pp. 001742-001744, DOI: 10.1109/ pvsc.2010.5615854.

60 S. H. Lee, H. S. Shim, C. K. Kim, J. H. Yoo, R. E. Russo and S. Jeong, Analysis of the absorption layer of CIGS solar cell by laser-induced breakdown spectroscopy, Appl. Opt., 2012, 51, B115, DOI: 10.1364/ao.51.00b115.

61 S.-H. Lee, C.-K. Kim, H.-S. Shim, J.-H. Yoo, R. E. Russo and S. Jeong, Ablation and spectroscopic characteristics of thin $\mathrm{CuIn}_{1-x} \mathrm{Ga}_{x} \mathrm{Se}_{2}$ solar cell films fabricated by co-evaporation and co-sputtering processes, International Journal of Precision Engineering and Manufacturing-Green Technology, 2014, 1, 17-24, DOI: 10.1007/s40684-014-0003-6.

62 S. H. Lee, C. K. Kim, J. H. In and S. H. Jeong, in Rapid Composition Analysis of Compound Semiconductor Thin Film Solar Cell by Laser Induced Breakdown Spectroscopy, ed. Y. Nakata, X. Xu, S. Roth and B. Neuenschwander, 2014, p. 896713, DOI: 10.1117/12.2041826.

63 D. Diego-Vallejo, H. J. Eichler and D. Ashkenasi, Inspection of thin-film solar cell processing by laser-induced breakdown spectroscopy and neural networks, in 2012 Int.
Symp. Optomechatronic Technol. (ISOT 2012), IEEE, 2012, pp. 1-2. DOI: 10.1109/isot.2012.6403264.

64 D. Diego-Vallejo, D. Ashkenasi, A. Lemke and H. J. Eichler, Selective ablation of copper-indium-diselenide solar cells monitored by laser-induced breakdown spectroscopy and classification methods, Spectrochim. Acta, Part B, 2013, 87, 92-99, DOI: 10.1016/j.sab.2013.06.012.

65 J.-H. Choi, H.-J. Lee, S.-H. Lee, J.-H. In and S. Jeong, Effects of spot size variation on the laser induced breakdown spectroscopy analysis of $\mathrm{Cu}(\mathrm{In}, \mathrm{Ga}) \mathrm{Se}_{2}$ solar cell, Thin Solid Films, 2018, 660, 314-319, DOI: 10.1016/j.tsf.2018.06.034.

66 J.-H. Choi, Y. Moon, S.-H. Lee, J.-H. In and S. Jeong, Wavelength dependence of the ablation characteristics of $\mathrm{Cu}(\mathrm{In}, \mathrm{Ga}) \mathrm{Se}_{2}$ solar cell films and its effects on laser induced breakdown spectroscopy analysis, International Journal of Precision Engineering and Manufacturing-Green Technology, 2016, 3, 167-171, DOI: 10.1007/s40684-0160021-7.

67 C. K. Kim, S. H. Lee, J. H. In, H.-S. Shim, D. S. Kim and S. Jeong, Comparison of thin-film and bulk $\mathrm{CuIn}_{1-x} \mathrm{Ga}_{x} \mathrm{Se}_{2}$ samples by laser induced breakdown spectroscopy, Thin Solid Films, 2013, 546, 393-397, DOI: 10.1016/j.tsf.2013.04.068.

68 C. K. Kim, J. H. In, S. H. Lee and S. Jeong, Influence of laser wavelength on the laser induced breakdown spectroscopy measurement of thin $\mathrm{CuIn}_{1-x} \mathrm{Ga}_{x} \mathrm{Se}_{2}$ solar cell films, Spectrochim. Acta, Part B, 2013, 88, 20-25, DOI: 10.1016/ j.sab.2013.07.012.

69 J.-H. In, C.-K. Kim, S.-H. Lee, H.-J. Lee and S. Jeong, Improvement of selenium analysis during laser-induced breakdown spectroscopy measurement of $\mathrm{CuIn}_{1-x} \mathrm{Ga}_{x} \mathrm{Se}_{2}$ solar cell films by self-absorption corrected normalization, J. Anal. At. Spectrom., 2013, 28, 1327, DOI: 10.1039/ c3ja50079a.

70 J.-H. In, C.-K. Kim, S.-H. Lee and S. Jeong, Reproducibility of CIGS thin film analysis by laser-induced breakdown spectroscopy, J. Anal. At. Spectrom., 2013, 28, 473, DOI: 10.1039/c3ja30298a.

71 J.-H. In, C.-K. Kim, S.-H. Lee, H.-S. Shim and S. Jeong, Quantitative analysis of $\mathrm{CuIn}_{1-x} \mathrm{Ga}_{x} \mathrm{Se}_{2}$ thin films with fluctuation of operational parameters using laser-induced breakdown spectroscopy, J. Anal. At. Spectrom., 2013, 28, 890, DOI: 10.1039/c3ja30284a.

72 J.-H. In, C.-K. Kim, S.-H. Lee, J.-H. Choi and S. Jeong, Rapid quantitative analysis of elemental composition and depth profile of $\mathrm{Cu}(\mathrm{In}, \mathrm{Ga}) \mathrm{Se}_{2}$ thin solar cell film using laserinduced breakdown spectroscopy, Thin Solid Films, 2015, 579, 89-94, DOI: 10.1016/j.tsf.2015.02.061.

73 E. Tognoni, G. Cristoforetti, S. Legnaioli, V. Palleschi, A. Salvetti, M. Mueller, U. Panne and I. Gornushkin, A numerical study of expected accuracy and precision in calibration-free laser-induced breakdown spectroscopy in the assumption of ideal analytical plasma, Spectrochim. Acta, Part B, 2007, 62, 1287-1302, DOI: 10.1016/ j.sab.2007.10.005.

74 C. Aragón and J. A. Aguilera, Direct analysis of aluminum alloys by CSigma laser-induced breakdown spectroscopy, 
Anal. Chim. Acta, 2018, 1009, 12-19, DOI: 10.1016/ j.aca.2018.01.019.

75 A. Alonso-Medina, A spectroscopic study of laser-induced tin-lead plasma: transition probabilities for spectral lines of Sn I, Spectrochim. Acta, Part B, 2010, 65, 158-166, DOI: 10.1016/j.sab.2010.01.002.

76 S. Pagnotta, E. Grifoni, S. Legnaioli, M. Lezzerini, G. Lorenzetti and V. Palleschi, Comparison of brass alloys composition by laser-induced breakdown spectroscopy and self-organizing maps, Spectrochim. Acta, Part B, 2015, 103-104, 70-75, DOI: 10.1016/j.sab.2014.11.008.

77 E. D'Andrea, B. Lazzerini, V. Palleschi and S. Pagnotta, Determining the composition of bronze alloys by means of high-dimensional feature selection and artificial neural networks, in Conf. Rec. - IEEE Instrum. Meas. Technol. Conf., 2015, DOI: 10.1109/i2mtc.2015.7151598.

78 R. Noll, H. Bette, A. Brysch, M. Kraushaar, I. Mönch, L. Peter and V. Sturm, Laser-induced breakdown spectrometry applications for production control and quality assurance in the steel industry, Spectrochim. Acta, Part B, 2001, 56, 637-649, DOI: 10.1016/s0584-8547(01)00214-2.

79 S. Legnaioli, G. Lorenzetti, L. Pardini, G. H. Cavalcanti and V. Palleschi, Applications of LIBS to the analysis of metals, 2014, DOI: 10.1007/978-3-642-45085-3_7.

80 D. Bulajic, G. Cristoforetti, M. Corsi, M. Hidalgo, S. Legnaioli, V. Palleschi, A. Salvetti, E. Tognoni, S. Green, D. Bates, A. Steiger, J. Fonseca, J. Martins, J. McKay, B. Tozer, D. Wells, R. Wells and M. A. Harith, Diagnostics of high-temperature steel pipes in industrial environment by laser-induced breakdown spectroscopy technique: the LIBSGRAIN project, Spectrochim. Acta, Part B, 2002, 57, 1181-1192, DOI: 10.1016/s0584-8547(02)00060-5.

81 M. Aimoto, H. Kondo, H. Yamamura and T. Toh, Inspection of the Defects of Steel by Using Laser Induced Breakdown Spectroscopy, Tetsu to Hagane, 2007, 93, 483-488, DOI: 10.2355/tetsutohagane.93.483.

82 M. Kraushaar, R. Noll and H.-U. Schmitz, Slag Analysis with Laser-Induced Breakdown Spectrometry, Appl. Spectrosc., 2003, 57, 1282-1287, DOI: 10.1366/000370203769699171.

83 V. Sturm, R. Fleige, M. de Kanter, R. Leitner, K. Pilz, D. Fischer, G. Hubmer and R. Noll, Laser-Induced Breakdown Spectroscopy for 24/7 Automatic Liquid Slag Analysis at a Steel Works, Anal. Chem., 2014, 86, 96879692, DOI: 10.1021/ac5022425.

84 M. A. Gondal, T. Hussain, Z. H. Yamani and A. H. Bakry, Study of hazardous metals in iron slag waste using laser induced breakdown spectroscopy, J. Environ. Sci. Health, Part A: Toxic/Hazard. Subst. Environ. Eng., 2007, 42, 767775, DOI: 10.1080/10934520701304443.

85 G. Lorenzetti, S. Legnaioli, E. Grifoni, S. Pagnotta and V. Palleschi, Laser-based continuous monitoring and resolution of steel grades in sequence casting machines, Spectrochim. Acta, Part B, 2015, 112, 1-5, DOI: 10.1016/ j.sab.2015.07.006.

86 L. M. Cabalín, T. Delgado, J. Ruiz, D. Mier and J. J. Laserna, Stand-off laser-induced breakdown spectroscopy for steelgrade intermix detection in sequence casting operations.
At-line monitoring of temporal evolution versus predicted mathematical model, Spectrochim. Acta, Part B, 2018, 146, 93-100, DOI: 10.1016/j.sab.2018.05.001.

87 T. Delgado, J. Ruiz, L. M. Cabalín and J. J. Laserna, Distinction strategies based on discriminant function analysis for particular steel grades at elevated temperature using stand-off LIBS, J. Anal. At. Spectrom., 2016, 31, 22422252, DOI: 10.1039/c6ja00219f.

88 D. Mier, P. Nazim Jalali, P. Ramirez Lopez, J. Gurel, A. Strondl, L. M. Cabalín, T. Delgado, J. Ruiz, J. Laserna, B. Campanella, S. Legnaioli, G. Lorenzetti, S. Pagnotta, F. Poggialini and V. Palleschi, A stochastic model of the process of sequence casting of steel, taking into account imperfect mixing, Appl. Phys. B: Lasers Opt., 2019, 125, 65, DOI: $10.1007 /$ s00340-019-7175-2.

89 Laser-Induced Breakdown Spectroscopy LIBS, Tecnar, https:/www.tecnar.com/online-chemistry-analyser/, accessed March 5, 2019.

90 J. Ruiz, A. González, L. M. Cabalín and J. J. Laserna, On-Line Laser-Induced Breakdown Spectroscopy Determination of Magnesium Coating Thickness on Electrolytically Galvanized Steel in Motion, Appl. Spectrosc., 2010, 64, 1342-1349, DOI: 10.1366/000370210793561510.

91 H. Balzer, M. Hoehne, R. Noll and V. Sturm, New approach to online monitoring of the Al depth profile of the hot-dip galvanised sheet steel using LIBS, Anal. Bioanal. Chem., 2006, 385, 225-233, DOI: 10.1007/s00216-006-0347-z.

92 H. Balzer, M. Hoehne, V. Sturm and R. Noll, Online coating thickness measurement and depth profiling of zinc coated sheet steel by laser-induced breakdown spectroscopy, Spectrochim. Acta, Part B, 2005, 60, 1172-1178, DOI: 10.1016/j.sab.2005.07.003.

93 T. O. Nagy, U. Pacher, A. Giesriegl, M. J. J. Weimerskirch and W. Kautek, Depth profiling of galvanoaluminiumnickel coatings on steel by UV- and VIS-LIBS, Appl. Surf. Sci., 2017, 418, 508-516, DOI: 10.1016/j.apsusc.2016.12.059.

94 U. Pacher, M. Dinu, T. O. Nagy, R. Radvan and W. Kautek, Multiple wavelength stratigraphy by laser-induced breakdown spectroscopy of Ni-Co alloy coatings on steel, Spectrochim. Acta, Part B, 2018, 146, 36-40, DOI: 10.1016/ j.sab.2018.04.006.

95 M. M. ElFaham, M. Okil and A. M. Mostafa, Limit of detection and hardness evaluation of some steel alloys utilizing optical emission spectroscopic techniques, Opt. Laser Technol., 2018, 108, 634-641, DOI: 10.1016/ j.optlastec.2018.07.022.

96 M. S. Afgan, Z. Hou and Z. Wang, Quantitative analysis of common elements in steel using a handheld $\mu$-LIBS instrument, J. Anal. At. Spectrom., 2017, 32, 1905-1915, DOI: $10.1039 / \mathrm{c} 7 \mathrm{ja00219j.}$

97 F. Sorrentino, G. Carelli, F. Francesconi, M. Francesconi, P. Marsili, G. Cristoforetti, S. Legnaioli, V. Palleschi and E. Tognoni, Fast analysis of complex metallic alloys by double-pulse time-integrated laser-induced breakdown spectroscopy, Spectrochim. Acta, Part B, 2009, 64, 10681072, DOI: 10.1016/j.sab.2009.07.037. 
98 V. Sturm, L. Peter and R. Noll, Steel Analysis with LaserInduced Breakdown Spectrometry in the Vacuum Ultraviolet, Appl. Spectrosc., 2000, 54, 1275-1278, DOI: 10.1366/0003702001951183.

99 C. M. Li, Z. M. Zou, X. Y. Yang, Z. Q. Hao, L. B. Guo, X. Y. Li, Y. F. Lu and X. Y. Zeng, Quantitative analysis of phosphorus in steel using laser-induced breakdown spectroscopy in air atmosphere, J. Anal. At. Spectrom., 2014, 29, 1432-1437, DOI: $10.1039 / \mathrm{c} 4 \mathrm{ja00036f.}$

100 D. Girón, T. Delgado, J. Ruiz, L. M. M. Cabalín and J. J. J. Laserna, In-situ monitoring and characterization of airborne solid particles in the hostile environment of a steel industry using stand-off LIBS, Measurement, 2018, 115, 1-10, DOI: 10.1016/j.measurement.2017.09.046.

101 M. Sabsabi and P. Cielo, Quantitative Analysis of Aluminum Alloys by Laser-Induced Breakdown Spectroscopy and Plasma Characterization, Appl. Spectrosc., 1995, 49, 499-507, DOI: 10.1366/ 0003702953964408.

102 C. Colón, G. Hatem, E. Verdugo, P. Ruiz and J. Campos, Measurement of the Stark broadening and shift parameters for several ultraviolet lines of singly ionized aluminum, J. Appl. Phys., 1993, 73, 4752-4758, DOI: 10.1063/1.353839.

103 M. Cirisan, M. Cvejić, M. R. Gavrilović, S. Jovićević, N. Konjević and J. Hermann, Stark broadening measurement of Al II lines in a laser-induced plasma, $J$. Quant. Spectrosc. Radiat. Transfer, 2014, 133, 652-662, DOI: 10.1016/j.jqsrt.2013.10.002.

104 S. Li, L. Liu, A. Yan, S. Huang, X. Huang, R. Chen, Y. Lu and K. Chen, A compact field-portable double-pulse laser system to enhance laser induced breakdown spectroscopy, Rev. Sci. Instrum., 2017, 88, 023109, DOI: 10.1063/1.4975597.

105 Q. L. L. Ma, V. Motto-Ros, W. Q. Q. Lei, M. Boueri, X. S. S. Bai, L. J. J. Zheng, H. P. P. Zeng and J. Yu, Temporal and spatial dynamics of laser-induced aluminum plasma in argon background at atmospheric pressure: interplay with the ambient gas, Spectrochim. Acta, Part B, 2010, 65, 896-907, DOI: 10.1016/ j.sab.2010.08.005.

106 A. K. Rai, F.-Y. Yueh and J. P. Singh, Laser-induced breakdown spectroscopy of molten aluminum alloy, Appl. Opt., 2003, 42, 2078, DOI: 10.1364/ao.42.002078.

107 DTE, https://www.dtequipment.com/, accessed March 5, 2019.

108 G. H. Cavalcanti, D. V. Teixeira, S. Legnaioli, G. Lorenzetti, L. Pardini and V. Palleschi, One-point calibration for calibration-free laser-induced breakdown spectroscopy quantitative analysis, Spectrochim. Acta, Part B, 2013, 87, 51-56, DOI: 10.1016/j.sab.2013.05.016.

109 T. Takahashi, B. Thornton, K. Ohki and T. Sakka, Calibration-free analysis of immersed brass alloys using long-ns-duration pulse laser-induced breakdown spectroscopy with and without correction for nonstoichiometric ablation, Spectrochim. Acta, Part B, 2015, 111, 8-14, DOI: 10.1016/j.sab.2015.06.009.
110 M. Corsi, G. Cristoforetti, M. Hidalgo, D. Iriarte, S. Legnaioli, V. Palleschi, A. Salvetti and E. Tognoni, Effect of laser-induced crater depth in laser-induced breakdown spectroscopy emission features, Appl. Spectrosc., 2005, 59, 853-860, DOI: 10.1366/ 0003702054411607.

111 A. Santagata, D. Spera, G. Albano, R. Teghil, G. P. Parisi, A. De Bonis and P. Villani, Orthogonal fs/ns double-pulse libs for copper-based-alloy analysis, Appl. Phys. A, 2008, 93, 929-934, DOI: 10.1007/s00339-008-4738-1.

112 A. Botto, B. Campanella, S. Legnaioli, M. Lezzerini, G. Lorenzetti, S. Pagnotta, F. Poggialini and V. Palleschi, Applications of laser-induced breakdown spectroscopy in cultural heritage and archaeology: a critical review, $J$. Anal. At. Spectrom., 2019, 34, 81-103, DOI: 10.1039/ c8ja00319j.

113 Ł. Łazarek, A. J. Antończak, M. R. Wójcik, J. Drzymała and K. M. Abramski, Evaluation of the laser-induced breakdown spectroscopy technique for determination of the chemical composition of copper concentrates, Spectrochim. Acta, Part B, 2014, 97, 74-78, DOI: 10.1016/ j.sab.2014.05.001.

114 S. Messaoud Aberkane, M. Abdelhamid, F. Mokdad, K. Yahiaoui, S. Abdelli-Messaci and M. A. Harith, Sorting zamak alloys via chemometric analysis of their LIBS spectra, Anal. Methods, 2017, 9, 3696-3703, DOI: 10.1039/ c7ay01138e.

115 M. D. Mowery, R. Sing, J. Kirsch, A. Razaghi, S. Béchard and R. A. Reed, Rapid at-line analysis of coating thickness and uniformity on tablets using laser induced breakdown spectroscopy, J. Pharm. Biomed. Anal., 2002, 28, 935-943, DOI: 10.1016/s0731-7085(01)00705-1.

116 L. St-Onge, J. F. Archambault, E. Kwong, M. Sabsabi and E. B. Vadas, Rapid quantitative analysis of magnesium stearate in tablets using laser-induced breakdown spectroscopy, J. Pharm. Pharm. Sci., 2005, 8, 272-288.

117 L. St-Onge, E. Kwong, M. Sabsabi and E. Vadas, Quantitative analysis of pharmaceutical products by laserinduced breakdown spectroscopy, Spectrochim. Acta, Part $B$, 2002, 57, 1131-1140, DOI: 10.1016/s0584-8547(02) 00062-9.

118 M. C. Madamba, W. M. Mullett, S. Debnath and E. Kwong, Characterization of tablet film coatings using a laserinduced breakdown spectroscopic technique, AAPS PharmSciTech, 2007, 8, 184-190, DOI: 10.1208/pt0804103.

119 G. G. Arantes de Carvalho, L. C. Nunes, P. Florêncio de Souza, F. J. Krug, T. C. Alegre and D. Santos Jr, Evaluation of laser induced breakdown spectrometry for the determination of macro and micronutrients in pharmaceutical tablets, J. Anal. At. Spectrom., 2010, 25, 803, DOI: 10.1039/c000703j.

120 A. K. Myakalwar, S. Sreedhar, I. Barman, N. C. Dingari, S. Venugopal Rao, P. Prem Kiran, S. P. Tewari and G. Manoj Kumar, Laser-induced breakdown spectroscopybased investigation and classification of pharmaceutical tablets using multivariate chemometric analysis, Talanta, 2011, 87, 53-59, DOI: 10.1016/j.talanta.2011.09.040. 
121 L. Zou, B. Kassim, J. P. Smith, J. D. Ormes, Y. Liu, Q. Tu and $\mathrm{X}$. Bu, In situ analytical characterization and chemical imaging of tablet coatings using laser induced breakdown spectroscopy (LIBS), Analyst, 2018, 143, 5000-5007, DOI: 10.1039/c8an01262h.

122 C. S. Yang, F. Jin, S. R. Swaminathan, S. Patel, E. D. Ramer, S. B. Trivedi, E. E. Brown, U. Hommerich and A. C. Samuels, Comprehensive study of solid pharmaceutical tablets in visible, near infrared (NIR), and longwave infrared (LWIR) spectral regions using a rapid simultaneous ultraviolet/ visible/NIR (UVN) + LWIR laser-induced breakdown spectroscopy linear arrays detection system and a fast acousto-optic tunable filter NIR spectrometer, Opt. Express, 2017, 25, 26885, DOI: 10.1364/oe.25.026885.

123 C. S.-C. Yang, E. E. Brown, E. Kumi-Barimah, U. H. Hommerich, F. Jin, S. B. Trivedi, A. C. Samuels and A. P. Snyder, Mid-Infrared, Long Wave Infrared (4-12 $\mu \mathrm{m})$ Molecular Emission Signatures from Pharmaceuticals Using Laser-Induced Breakdown Spectroscopy (LIBS), Appl. Spectrosc., 2014, 68, 226-231, DOI: 10.1366/13-07141.

124 L. Zhan-feng, W. Rui-wen, D. Hu and S. Li-ping, Laser Induced Breakdown Spectros Copy of $\mathrm{Cu}$ in Coptis Chinensis, Aconite Root and Poria Cocos, Chin. J. Lumin., 2016, 37, 100-105, DOI: 10.3788/fgxb20163701.0100.

125 J. Wang, X. Liao, P. Zheng, S. Xue and R. Peng, Classification of Chinese Herbal Medicine by LaserInduced Breakdown Spectroscopy with Principal Component Analysis and Artificial Neural Network, Anal. Lett., 2018, 51, 575-586, DOI: 10.1080/ 00032719.2017 .1340949 .

126 X. Liu, Q. Ma, S. Liu, X. Shi, Q. Zhang, Z. Wu and Y. Qiao, Monitoring As and $\mathrm{Hg}$ variation in An-Gong-Niu-Huang Wan (AGNH) intermediates in a pilot scale blending process using laser-induced breakdown spectroscopy, Spectrochim. Acta, Part A, 2015, 151, 547-552, DOI: 10.1016/j.saa.2015.07.002.

127 A. V. Pakhomov, W. Nichols and J. Borysow, Laser-Induced Breakdown Spectroscopy for Detection of Lead in Concrete, Appl. Spectrosc., 1996, 50, 880-884, DOI: 10.1366/ 0003702963905538.

128 T. A. Labutin, A. M. Popov, S. M. Zaytsev, N. B. Zorov, M. V. Belkov, V. V. Kiris and S. N. Raikov, Determination of chlorine, sulfur and carbon in reinforced concrete structures by double-pulse laser-induced breakdown spectroscopy, Spectrochim. Acta, Part B, 2014, 99, 94-100, DOI: 10.1016/j.sab.2014.06.021.

129 F. Weritz, S. Ryahi, D. Schaurich, A. Taffe and G. Wilsch, Quantitative determination of sulfur content in concrete with laser-induced breakdown spectroscopy, Spectrochim. Acta, Part B, 2005, 60, 1121-1131, DOI: 10.1016/ j.sab.2005.05.036.

130 M. A. Gondal, A. Dastageer, M. Maslehuddin, A. J. Alnehmi and O. S. B. Al-Amoudi, Detection of sulfur in the reinforced concrete structures using a dual pulsed LIBS system, Opt. Laser Technol., 2012, 44, 566-571, DOI: 10.1016/j.optlastec.2011.09.001.
131 A. Hrdlička, J. Hegrová, K. Novotný, V. Kanický, D. Prochazka, J. Novotný, P. Modlitbová, L. Sládková, P. Pořizka and J. Kaiser, Sulfur determination in concrete samples using laser-induced breakdown spectroscopy and limestone standards, Spectrochim. Acta, Part B, 2018, 142, 8-13, DOI: 10.1016/j.sab.2018.01.015.

132 C. Gottlieb, S. Millar, T. Günther and G. Wilsch, Revealing hidden spectral information of chlorine and sulfur in data of a mobile laser-induced breakdown spectroscopy system using chemometrics, Spectrochim. Acta, Part B, 2017, 132, 43-49, DOI: 10.1016/j.sab.2017.04.001.

133 C. D. Gehlen, E. Wiens, R. Noll, G. Wilsch and K. Reichling, Chlorine detection in cement with laser-induced breakdown spectroscopy in the infrared and ultraviolet spectral range, Spectrochim. Acta, Part B, 2009, 64, 11351140, DOI: 10.1016/j.sab.2009.07.021.

134 S. Millar, C. Gottlieb, T. Günther, N. Sankat, G. Wilsch and S. Kruschwitz, Chlorine determination in cement-bound materials with laser-induced breakdown spectroscopy (LIBS) - a review and validation, Spectrochim. Acta, Part B, 2018, 147, 1-8, DOI: 10.1016/j.sab.2018.05.015.

135 K. Sugiyama, T. Fujii, T. Matsumura, Y. Shiogama, M. Yamaguchi and K. Nemoto, Detection of chlorine with concentration of $018 \mathrm{~kg} / \mathrm{m}^{3}$ in concrete by laser-induced breakdown spectroscopy, Appl. Opt., 2010, 49, C181, DOI: 10.1364/ao.49.00c181.

136 T. A. Labutin, A. M. Popov, S. N. Raikov, S. M. Zaytsev, N. A. Labutina and N. B. Zorov, Determination of chlorine in concrete by laser-induced breakdown spectroscopy in air, J. Appl. Spectrosc., 2013, 80, 315-318, DOI: 10.1007/ s10812-013-9766-8.

137 B. Šavija, E. Schlangen, J. Pacheco, S. Millar, T. Eichler and G. Wilsch, Chloride ingress in cracked concrete: a laser induced breakdown spectroscopy (LIBS) study, J. Adv. Concr. Technol., 2014, 12, 425-442, DOI: 10.3151/ jact.12.425.

138 J. Mateo, M. C. Quintero, J. M. Fernández, M. C. García and A. Rodero, Application of LIBS technology for determination of $\mathrm{Cl}$ concentrations in mortar samples, Constr. Build. Mater., 2019, 204, 716-726, DOI: 10.1016/ j.conbuildmat.2019.01.152.

139 D. E. Anderson, B. L. Ehlmann, O. Forni, S. M. Clegg, A. Cousin, N. H. Thomas, J. Lasue, D. M. Delapp, R. E. McInroy, O. Gasnault, M. D. Dyar, S. Schröder, S. Maurice and R. C. Wiens, Characterization of LIBS emission lines for the identification of chlorides, carbonates, and sulfates in salt/basalt mixtures for the application to MSL ChemCam data, J. Geophys. Res.: Planets, 2017, 122, 744-770, DOI: 10.1002/2016je005164.

140 G. Wilsch, T. Eichler, S. Millar and C. Gottlieb, Quantitative Determination of Chloride-to-Cement Content of Concrete by Laser-Induced Breakdown pectroscopy (LIBS), in CONCREEP 10, American Society of Civil Engineers, Reston, VA, 2015, pp. 815-822, DOI: 10.1061/ 9780784479346.097.

141 N. Omenetto, W. B. Jones, B. W. Smith, T. Guenther, E. Ewusi-Annan and U. of Florida, Feasibility of Atomic 
and Molecular Laser Induced Breakdown Spectroscopy (LIBS) to In-situ Determination of Chlorine in Concrete: Final Report, 2016, https://rosap.ntl.bts.gov/view/dot/31477, accessed February 17, 2019.

142 L. Caneve, F. Colao, F. Fabbri, R. Fantoni, V. Spizzichino and J. Striber, Laser-induced breakdown spectroscopy analysis of asbestos, Spectrochim. Acta, Part B, 2005, 60, 1115-1120, DOI: 10.1016/j.sab.2005.05.014.

143 J. Anzano, B. Bonilla, B. Montull-Ibor and J. CasasGonzález, Plastic identification and comparison by multivariate techniques with laser-induced breakdown spectroscopy, J. Appl. Polym. Sci., 2011, 121, 2710-2716, DOI: 10.1002/app.33801.

144 S. Grégoire, M. Boudinet, F. Pelascini, F. Surma, V. Detalle and Y. Holl, Laser-induced breakdown spectroscopy for polymer identification, Anal. Bioanal. Chem., 2011, 400, 3331-3340, DOI: 10.1007/s00216-011-4898-2.

145 V. C. Costa, F. W. B. Aquino, C. M. Paranhos and E. R. Pereira-Filho, Identification and classification of polymer e-waste using laser-induced breakdown spectroscopy (LIBS) and chemometric tools, Polym. Test., 2017, 59, 390-395, DOI: 10.1016/ j.polymertesting.2017.02.017.

146 M. Vahid Dastjerdi, S. J. Mousavi, M. Soltanolkotabi and A. Nezarati Zadeh, Identification and Sorting of PVC Polymer in Recycling Process by Laser-Induced Breakdown Spectroscopy (LIBS) Combined with Support Vector Machine (SVM) Model, Iran. J. Sci. Technol. Trans. A-Science, 2018, 42, 959-965, DOI: 10.1007/s40995-0160084-x.

147 R. Glaus and D. W. Hahn, Fiber-coupled laser-induced breakdown and Raman spectroscopy for flexible sample characterization with depth profiling capabilities, Spectrochim. Acta, Part B, 2014, 100, 116-122, DOI: 10.1016/j.sab.2014.06.026.

148 S. Legnaioli, G. Lorenzetti, L. Pardini, V. Palleschi, D. M. D. Pace, F. A. Garcia, R. Grassi, F. Sorrentino, G. Carelli, M. Francesconi, F. Francesconi and R. Borgogni, Laser-induced breakdown spectroscopy application to control of the process of precious metal recovery and recycling, Spectrochim. Acta, Part B, 2012, 7172, DOI: 10.1016/j.sab.2012.05.004.

149 F. W. B. Aquino, J. M. Santos, R. R. V. Carvalho, J. A. O. Coelho and E. R. Pereira-Filho, Obtaining information about valuable metals in computer and mobile phone scraps using laser-induced breakdown spectroscopy (LIBS), RSC Adv., 2015, 5, 67001-67010, DOI: 10.1039/c5ra07609a.

150 V. C. Costa, F. W. B. Aquino, C. M. Paranhos and E. R. Pereira-Filho, Use of laser-induced breakdown spectroscopy for the determination of polycarbonate (PC) and acrylonitrile-butadiene-styrene (ABS) concentrations in PC/ABS plastics from e-waste, Waste Manag., 2017, 70, 212-221, DOI: 10.1016/j.wasman.2017.09.027.

151 F. W. B. Aquino and E. R. Pereira-Filho, Analysis of the polymeric fractions of scrap from mobile phones using laser-induced breakdown spectroscopy: chemometric applications for better data interpretation, Talanta, 2015, 134, 65-73, DOI: 10.1016/j.talanta.2014.10.051.

152 B. Campanella, E. Grifoni, S. Legnaioli, G. Lorenzetti, S. Pagnotta, F. Sorrentino and V. Palleschi, Classification of wrought aluminum alloys by ANN evaluation of LIBS spectra from aluminum scrap samples, Spectrochim. Acta, Part B, 2017, 134, 52-57, DOI: 10.1016/j.sab.2017.06.003.

$153 \mathrm{Home} / \mathrm{SECOPTA}$ analytics GmbH, https:// www.secopta.com/, accessed March 5, 2019.

154 REFRASORT - Project, https://esites.vito.be/sites/refrasort/ Pages/Project.aspx, accessed March 5, 2019.

155 L. Peng, D. Sun, M. Su, J. Han and C. Dong, Rapid analysis on the heavy metal content of spent zinc-manganese batteries by laser-induced breakdown spectroscopy, opt. Laser Technol., 2012, 44, 2469-2475, DOI: 10.1016/ j.optlastec.2012.01.036.

156 D. Díaz, D. W. Hahn and A. Molina, Quantification of gold and silver in minerals by laser-induced breakdown spectroscopy, Spectrochim. Acta, Part B, 2017, 136, 106115, DOI: 10.1016/j.sab.2017.08.008.

157 D. Díaz, A. Molina and D. Hahn, Effect of laser irradiance and wavelength on the analysis of gold- and silver-bearing minerals with laser-induced breakdown spectroscopy, Spectrochim. Acta, Part B, 2018, 145, 86-95, DOI: 10.1016/ j.sab.2018.04.007.

158 L. Sheng, T. Zhang, K. Wang, H. Tang and H. Li, Quantitative analysis of Fe content in iron ore via external calibration in conjunction with internal standardization method coupled with LIBS, Chem. Res. Chin. Univ., 2015, 31, 107-111, DOI: 10.1007/s40242-014-4318-1.

159 Y. M. Guo, L. B. Guo, Z. Q. Hao, Y. Tang, S. X. Ma, Q. D. Zeng, S. S. Tang, X. Y. Li, Y. F. Lu and X. Y. Zeng, Accuracy improvement of iron ore analysis using laserinduced breakdown spectroscopy with a hybrid sparse partial least squares and least-squares support vector machine model, J. Anal. At. Spectrom., 2018, 33, 13301335, DOI: 10.1039/c8ja00119g.

160 N. Ahmad, R. Ahmed, Z. A. Umar, U. Liaqat, U. Manzoor and M. A. Baig, Qualitative and quantitative analyses of copper ores collected from Baluchistan, Pakistan using LIBS and LA-TOF-MS, Appl. Phys. B: Lasers Opt., 2018, 124, 160, DOI: $10.1007 / \mathrm{s} 00340-018-7032-8$.

161 G. S. Senesi, Laser-induced breakdown spectroscopy (LIBS) applied to terrestrial and extraterrestrial analogue geomaterials with emphasis to minerals and rocks, EarthSci. Rev., 2014, 139, 231-267, DOI: 10.1016/ j.earscirev.2014.09.008.

162 G. Yang, X. Han, C. Wang, Y. Ding, K. Liu, D. Tian and L. Yao, The basicity analysis of sintered ore using laserinduced breakdown spectroscopy (LIBS) combined with random forest regression (RFR), Anal. Methods, 2017, 9, 5365-5370, DOI: 10.1039/c7ay01389b.

163 M. Gaft, I. Sapir-Sofer, H. Modiano and R. Stana, Laser induced breakdown spectroscopy for bulk minerals online analyses, Spectrochim. Acta, Part B, 2007, 62, 14961503, DOI: 10.1016/j.sab.2007.10.041. 
164 M. Gaft, L. Nagli, Y. Groisman and A. Barishnikov, Industrial Online Raw Materials Analyzer Based on LaserInduced Breakdown Spectroscopy, Appl. Spectrosc., 2014, 68, 1004-1015, DOI: 10.1366/13-07382.

165 R. Grassi, E. Grifoni, S. Gufoni, S. Legnaioli, G. Lorenzetti, N. Macro, L. Menichetti, S. Pagnotta, F. Poggialini, C. Schiavo and V. Palleschi, Three-dimensional compositional mapping using double-pulse micro-laserinduced breakdown spectroscopy technique, Spectrochim. Acta, Part B, 2017, 127, 1-6, DOI: 10.1016/j.sab.2016.11.004.

166 J. R. Chirinos, D. D. Oropeza, J. J. Gonzalez, H. Hou, M. Morey, V. Zorba and R. E. Russo, Simultaneous 3dimensional elemental imaging with LIBS and LA-ICPMS, J. Anal. At. Spectrom., 2014, 29, 1292-1298, DOI: 10.1039/c4ja00066h.

167 L. Jolivet, M. Leprince, S. Moncayo, L. Sorbier, C.-P. Lienemann and V. Motto-Ros, Review of the recent advances and applications of LIBS-based imaging, Spectrochim. Acta, Part B, 2019, 151, 41-53, DOI: 10.1016/ j.sab.2018.11.008.

168 ELEMISSION, Libs Technology, https://www.elemission.ca/ en/, accessed March 5, 2019.

169 K. Rifai, F. Doucet, L. Özcan and F. Vidal, LIBS core imaging at $\mathrm{kHz}$ speed: paving the way for real-time geochemical applications, Spectrochim. Acta, Part B, 2018, 150, 43-48, DOI: 10.1016/j.sab.2018.10.007.

170 B. Sezer, G. Bilge and I. H. Boyaci, Capabilities and limitations of LIBS in food analysis, TrAC, Trends Anal. Chem., 2017, 97, 345-353, DOI: 10.1016/j.trac.2017.10.003.

171 T. V. Silva, D. M. B. P. Milori, J. A. G. Neto, E. J. Ferreira and E. C. Ferreira, Prediction of black, immature and sour defective beans in coffee blends by using laser-induced breakdown spectroscopy, Food Chem., 2019, 278, 223-227, DOI: 10.1016/j.foodchem.2018.11.062.

172 A. A. I. Khalil and O. A. Labib, Detection of micro-toxic elements in commercial coffee brands using optimized dual-pulsed laser-induced spectral analysis spectrometry, Appl. Opt., 2018, 57, 6729, DOI: 10.1364/ao.57.006729.

173 B. Sezer, H. Apaydin, G. Bilge and I. H. Boyaci, Coffee arabica adulteration: detection of wheat, corn and chickpea, Food Chem., 2018, 264, 142-148, DOI: 10.1016/ j.foodchem.2018.05.037.

174 B. Sezer, S. Durna, G. Bilge, A. Berkkan, A. Yetisemiyen and I. H. Boyaci, Identification of milk fraud using laserinduced breakdown spectroscopy (LIBS), Int. Dairy J., 2018, 81, 1-7, DOI: 10.1016/j.idairyj.2017.12.005.

175 G. Bilge, B. Sezer, K. E. Eseller, H. Berberoglu, A. Topcu and I. H. Boyaci, Determination of whey adulteration in milk powder by using laser induced breakdown spectroscopy, Food Chem., 2016, 212, 183-188, DOI: 10.1016/ j.foodchem.2016.05.169.

176 S. Moncayo, S. Manzoor, J. D. D. Rosales, J. Anzano and J. O. O. Caceres, Qualitative and quantitative analysis of milk for the detection of adulteration by laser induced breakdown spectroscopy (LIBS), Food Chem., 2017, 232, 322-328, DOI: 10.1016/j.foodchem.2017.04.017.
177 Z. Abdel-Salam, J. Al Sharnoubi and M. A. Harith, Qualitative evaluation of maternal milk and commercial infant formulas via LIBS, Talanta, 2013, 115, 422-426, DOI: 10.1016/j.talanta.2013.06.003.

178 A. dos Santos Augusto, P. L. Barsanelli, F. M. V. Pereira and E. R. Pereira-Filho, Calibration strategies for the direct determination of $\mathrm{Ca}, \mathrm{K}$, and $\mathrm{Mg}$ in commercial samples of powdered milk and solid dietary supplements using laser-induced breakdown spectroscopy (LIBS), Food Res. Int., 2017, 94, 72-78, DOI: 10.1016/j.foodres.2017.01.027.

179 E. C. Ferreira, E. A. Menezes, W. O. Matos, D. M. B. P. Milori, A. R. A. Nogueira and L. Martin-Neto, Determination of $\mathrm{Ca}$ in breakfast cereals by laser induced breakdown spectroscopy, Food Control, 2010, 21, 13271330, DOI: 10.1016/j.foodcont.2010.04.004.

180 M. A. Gondal, Y. B. Habibullah, U. Baig and L. E. Oloore, Direct spectral analysis of tea samples using $266 \mathrm{~nm} \mathrm{UV}$ pulsed laser-induced breakdown spectroscopy and cross validation of LIBS results with ICP-MS, Talanta, 2016, 152, 341-352, DOI: 10.1016/j.talanta.2016.02.030.

181 H. Zhang, Q. Zhu, M. Huang and Y. Guo, Automatic determination of optimal spectral peaks for classification of Chinese tea leaves using laser-induced breakdown spectroscopy, Int. J. Agric. Biol. Eng., 2018, 11, 154-158, DOI: 10.25165/j.ijabe.20181103.3482.

182 K. W. Se, S. K. Ghoshal and R. A. Wahab, Laser-induced breakdown spectroscopy unified partial least squares regression: an easy and speedy strategy for predicting $\mathrm{Ca}$, $\mathrm{Mg}$ and $\mathrm{Na}$ content in honey, Measurement, 2019, 136, 110, DOI: 10.1016/j.measurement.2018.12.052.

183 J. Peng, F. Liu, F. Zhou, K. Song, C. Zhang, L. Ye and Y. He, Challenging applications for multi-element analysis by laser-induced breakdown spectroscopy in agriculture: a review, TrAC, Trends Anal. Chem., 2016, 85, 260-272, DOI: $10.1016 /$ j.trac.2016.08.015.

184 C. Eum, D. Jang, J. Kim, S. Choi, K. Cha and H. Chung, Improving the accuracy of spectroscopic identification of geographical origins of agricultural samples through cooperative combination of near-infrared and laserinduced breakdown spectroscopy, Spectrochim. Acta, Part B, 2018, 149, 281-287, DOI: 10.1016/j.sab.2018.09.004.

185 B. M. Atta, M. Saleem, S. U. Haq, H. Ali, Z. Ali and M. Qamar, Determination of zinc and iron in wheat using laser-induced breakdown spectroscopy, Laser Phys. Lett., 2018, 15, 125603, DOI: 10.1088/1612-202x/aaea6e.

186 B. Sezer, G. Bilge and I. H. Boyaci, Laser-Induced Breakdown Spectroscopy Based Protein Assay for Cereal Samples, J. Agric. Food Chem., 2016, 64, 9459-9463, DOI: 10.1021/acs.jafc.6b04828.

187 T. Shen, W. Kong, F. Liu, Z. Chen, J. Yao, W. Wang, J. Peng, H. Chen and Y. He, Rapid Determination of Cadmium Contamination in Lettuce Using Laser-Induced Breakdown Spectroscopy, Molecules, 2018, 23, 2930, DOI: 10.3390/molecules23112930.

188 B. Sezer, H. M. Velioglu, G. Bilge, A. Berkkan, N. Ozdinc, U. Tamer and I. H. Boyaci, Detection and quantification of a toxic salt substitute ( $\mathrm{LiCl}$ ) by using laser induced 
breakdown spectroscopy (LIBS), Meat Sci., 2018, 135, 123128, DOI: 10.1016/j.meatsci.2017.09.010.

189 G. Bilge, H. M. Velioglu, B. Sezer, K. E. Eseller and I. H. Boyaci, Identification of meat species by using laserinduced breakdown spectroscopy, Meat Sci., 2016, 119, 118-122, DOI: 10.1016/j.meatsci.2016.04.035.

190 Y. W. Chu, S. S. Tang, S. X. Ma, Y. Y. Ma, Z. Q. Hao, Y. M. Guo, L. B. Guo, Y. F. Lu and X. Y. Zeng, Accuracy and stability improvement for meat species identification using multiplicative scatter correction and laser-induced breakdown spectroscopy, Opt. Express, 2018, 26, 10119, DOI: 10.1364/oe.26.010119.

191 H. M. Velioglu, B. Sezer, G. Bilge, S. E. Baytur and I. H. Boyaci, Identification of offal adulteration in beef by laser induced breakdown spectroscopy (LIBS), Meat Sci., 2018, 138, 28-33, DOI: 10.1016/j.meatsci.2017.12.003.

192 M. P. Casado-Gavalda, Y. Dixit, D. Geulen, R. CamaMoncunill, X. Cama-Moncunill, M. Markiewicz-Keszycka, P. J. Cullen and C. Sullivan, Quantification of copper content with laser induced breakdown spectroscopy as a potential indicator of offal adulteration in beef, Talanta, 2017, 169, 123-129, DOI: 10.1016/j.talanta.2017.03.071.

193 Y. Dixit, M. P. Casado-Gavalda, R. Cama-Moncunill, X. Cama-Moncunill, M. Markiewicz-Keszycka, F. Jacoby, P. J. Cullen and C. Sullivan, Introduction to laser induced breakdown spectroscopy imaging in food: salt diffusion in meat, J. Food Eng., 2018, 216, 120-124, DOI: 10.1016/ j.jfoodeng.2017.08.010.

194 Y. Dixit, M. P. Casado-Gavalda, R. Cama-Moncunill, M. Markiewicz-Keszycka, X. Cama-Moncunill, P. J. Cullen and C. Sullivan, Quantification of rubidium as a trace element in beef using laser induced breakdown spectroscopy, Meat Sci., 2017, 130, 47-49, DOI: 10.1016/ j.meatsci.2017.03.013.

195 M.-B. S. Andersen, J. Frydenvang, P. Henckel and $\AA$. Rinnan, The potential of laser-induced breakdown spectroscopy for industrial at-line monitoring of calcium content in comminuted poultry meat, Food Control, 2016, 64, 226-233, DOI: 10.1016/j.foodcont.2016.01.001. 